\title{
Phaseolinae (Leguminosae, Papilionoideae, Phaseoleae) no estado do Paraná, Brasil ${ }^{1}$
}

\author{
Phaseolinae (Leguminosae, Papilionoideae, Phaseoleae) in the State of Paraná, Brazil
}

\author{
Cristiane Snak ${ }^{2,4}$, Silvia Teresinha Sfoggia Miotto ${ }^{3} \&$ Renato Goldenberg $^{2}$
}

\begin{abstract}
Resumo
No Paraná, a subtribo Phaseolinae Benth. está representada por 20 espécies, alocadas em quatro gêneros. Vigna Savi apresentou o maior número de espécies (12), seguido de Macroptilium (Benth.) Urb. (5), Phaseolus L. (2) e Lablab Adans. (1), sendo os dois últimos gêneros representados apenas por espécies cultivadas. Segundo os critérios da IUCN, cinco espécies foram classificadas como ameaçadas. As espécies ocorrem nos mais diversos ambientes, desde restinga, estepe e cerrado até habitats úmidos, como margens de rios. O Paraná representa o limite sul de ocorrência no Brasil para três espécies. São fornecidos chaves de identificação, ilustrações, descrições e comentários taxonômicos, biogeográficos, sobre floração e frutificação. Palavras-chave: Fabaceae, leguminosas, Macroptilium, Vigna .
\end{abstract}

\begin{abstract}
Subtribe Phaseolinae Benth. has 20 species in four genera in the Brazilian State of Paraná. Vigna Savi has the largest number of species (12), followed by Macroptilium (Benth.) Urb (5), Phaseolus L. (2), and Lablab Adans. (1). The latter two genera are represented by only cultivated species. According to IUCN criteria five species were classified as threatened. The species occur in different vegetation types, including restinga (sand dune vegetation), estepe (grasslands), cerrado (savanna-like vegetation), and moist habitats, like riverbanks. Paraná is the southern limit of distribution for three species in Brazil. We provide identification keys, illustrations, descriptions, and comments on taxonomy, biogeography, and flowering and fruiting periods of the species.
\end{abstract}

Key words: Fabaceae, legumes, Macroptilium, Vigna.

\section{Introdução}

Leguminosae Juss. compreende 727 gêneros e cerca de 19.400 espécies, está distribuída em todos os continentes, com exceção da Antártida, e possui como centro de diversidade as regiões tropicais (Lewis et al. 2005). A família é monofilética e tradicionalmente dividida em três subfamílias: Caesalpinioideae, Mimosoideae e Papilionoideae (Wojciechowski 2003, 2004; Lewis et al. 2005).

A classificação de várias Leguminosae com caule volúvel e trifolioladas em um mesmo grupo remonta a Linnaeus (1753). Porém, foi De Candolle (1825) quem fez a primeira proposta de classificação da tribo Phaseoleae DC., onde estão incluídos os gêneros com estas características. Mais tarde, Bentham (1837) se aprofundou mais nos estudos do grupo e propôs uma classificação com várias subtribos, dentre as quais Phaseolinae Benth. A subtribo Phaseolinae é monofilética (com a exclusão do gênero Psophocarpus DC.), apresenta como sinapomorfia uma grande inversão de $78 \mathrm{~kb}$ no $c p$ DNA e está proximamente relacionada com a subtribo Glycininae e a tribo Psoraleeae (Bruneau et al. 1990, 1995; Doyle \& Doyle 1993; Shrire 2005; Stefanovic et al. 2009).

Phaseolinae compreende 21 gêneros e cerca de 315 espécies, com distribuição pantropical (Shrire 2005). Destas, cerca de 118 espécies estão presentes nos neotrópicos e subtrópicos (Shrire 2005). No Brasil ocorrem seis gêneros e cerca de 32 espécies (Lima et al. 2010). As Phaseolinae muitas vezes apresentam características de plantas

Este artigo possui material adicional em sua versão eletrônica.

\footnotetext{
${ }^{1}$ Parte da dissertação de Mestrado da primeira autora.

${ }^{2}$ Universidade Federal do Paraná, Depto. Botânica, 81531-970, Curitiba, PR.

${ }^{3}$ Universidade Federal do Rio Grande do Sul, Depto. Botânica, 91501-970, Porto Alegre, RS.

${ }^{4}$ Autor para correspondência: cristianesnak@hotmail.com
} 
invasoras e/ou potencial econômico e, por este motivo, são amplamente difundidas e cultivadas (Burkart 1943; Steele \& Mehra 1980).

Historicamente, Phaseolinae foi alvo de muitas controvérsias, devido à sua taxonomia problemática, principalmente na delimitação genérica do complexo Phaseolus-Vigna e grupos relacionados. A delimitação taxonômica dos gêneros foi se estabelecendo gradativamente até que Maréchal et al. (1978) determinaram os limites entre os gêneros da subtribo, assim como estabeleceram suas categorias infragenéricas.

Até o momento, Phaseolinae foi tema de poucos estudos no Brasil. Foi abordada no trabalho de Fevereiro \& Barbosa-Fevereiro (1980), que estudaram a subtribo no estado da Paraíba e por Moreira (1997), que estudou a subtribo nas regiões Sudeste e CentroOeste do Brasil. Já Barbosa-Fevereiro (1987) e LeitãoFilho (1974) revisaram respectivamente Macroptilium (Benth.) Urb. e PhaseolusL. para o Brasil.

Considerando a riqueza de espécies de Phaseolinae mencionadas para o Paraná (15 spp.) (Lima et al. 2010) e a escassez de informações atualizadas sobre o grupo, este trabalho teve como objetivo realizar um estudo taxonômico da subtribo Phaseolinae no estado. São fornecidas chaves de identificação, ilustrações, descrições e comentários taxonômicos, biogeográficos, sobre a floração e frutificação.

\section{Material e Métodos}

\section{Área de estudo}

O estado do Paraná está localizado na região Sul do Brasil, entre as latitudes $22^{\circ} 29^{\prime} 30^{\prime \prime}$ e 2642'59” S e longitudes $48^{\circ} 02^{\prime} 24^{\prime \prime}$ e $54^{\circ} 37^{\prime} 38^{\prime \prime} \mathrm{W}$, limitando-se ao norte com o estado de São Paulo, a leste com o Oceano Atlântico, ao sul com Santa Catarina e a oeste com Mato Grosso do Sul, Paraguaie Argentina (Maack 1981).

No Paraná são encontrados dois tipos climáticos: clima subtropical (Cfa), com verões quentes, geadas pouco frequentes e tendência de concentração das chuvas nos meses de verão e clima temperado propriamente dito $(\mathrm{Cfb})$, com verões frescos, ambos sem estação seca definida (IAPAR 2000).

As terras do estado estão agrupadas em cinco unidades geomorfológicas que se sucedem de leste para oeste, denominadas Região Litorânea, Serra do Mar, Primeiro Planalto ou de Curitiba, Segundo Planalto ou de Ponta Grossa e Terceiro Planalto ou de Guarapuava (Maack 1981). Segundo Roderjan et al. (2002), no Paraná destacam-se cinco unidades fitofisionômicas: floresta ombrófila densa; floresta ombrófila mista; floresta estacional semidecidual; savana (cerrado) e estepe (campo). No restante do Paraná ocorrem restingas litorâneas, manguezais, várzeas, campos de altitude e vegetação rupestre.

\section{Coleta de dados e tratamento do material botânico}

Foram analisadas as coleções dos herbários do Paraná: FUEL, HCF, HUEM, HUPG, MBM, UNOP (não indexado) e UPCB e análises adicionais foram feitas nas coleções de A, B, BM, C, CESJ, E, F, GB, GH, HB, IAC, ICN, LL, MA, MICH, MO, NY, R, RB, SP, SPF, UC, UEC, VIC (acrônimos segundo NYBG 2008). Foram citadas como material selecionado apenas exsicatas provenientes do Paraná e limitadas a apenas uma exsicata por município. No total foram estudadas cerca de 450 exsicatas, dentre as quais 30 a partir de coletas próprias durante a realização de 20 expedições a campo em diferentes regiões do Estado. O material coletado foi herborizado segundo técnicas descritas por Bridson \& Forman (2004) e encontra-se depositado no herbário UPCB.

As identificações dos táxons foram feitas com base em literatura especializada, destacando-se Maréchal et al. (1978), Barbosa-Fevereiro (1987) e Moreira (1997). Sempre que possível foram consultadas as descrições originais. A delimitação das espécies adotada neste trabalho foi a partir da análise dos materiais-tipos e de acordo com a revisão taxonômica mais recente de Maréchal et al. (1978).

A nomenclatura morfológica usada nas descrições foi baseada nos trabalhos de Radford et al. (1974), Maréchal et al. (1978) e Polhill \& Raven (1981). Os nomes dos autores de cada espécie foram abreviados de acordo com Brummit \& Powell (1992).

As descrições genéricas e específicas foram baseadas na amplitude das variações morfológicas observadas no material coletado no Paraná. A versão on-line da revista contém um Apêndice onde as Figuras aqui apresentadas estão reorganizadas conforme suas estruturas morfológicas, visando a comparação entre as mesmas, a fim de evidenciar as variações entre os táxons.

Comentários sobre a distribuição geográfica foram obtidos na literatura e após análise do material coletado no estado, as unidades da federação estão abreviadas pelas respectivas siglas designativas.

As espécies foram analisadas, para efeito de avaliação do seu estado de conservação, de acordo com as categorias e critérios da IUCN $(2001,2003)$. A análise foi restrita ao estado do Paraná e teve por base apenas os critérios B (distribuição geográfica na forma de extensão da presença e/ou área de ocupação). 


\section{Resultados e Discussão}

\section{Tratamento taxonômico}

Phaseolinae Benth., Comm. Leg. Gen.: 49. 1987.

Arbustos, subarbustos ou ervas, eretos, prostrados ou volúveis. Tricomas uncinados ou não. Estípulas expandidas abaixo do ponto de inserção ou não. Folhas trifolioladas. Inflorescência pseudoracemosa, axilar ou terminal. Cálice campanulado ou tubuloso, 4-5-denteado; estandarte simétrico ou assimétrico; asas maiores, menores ou de igual tamanho às outras pétalas; pétalas da quilha planas, lateralmente torcidas, cocleadas ou espiraladas; androceu diadelfo (9) + 1; anteras rimosas, dorsifixas; ovário estipitado; estilete barbado, prolongado além do ponto de inserção do estigma ou não; estigma terminal, oblíquo ou lateral.
Phaseolinae pode ser facilmente reconhecida pela combinação dos seguintes caracteres: hábito geralmente volúvel, folhas trifolioladas, pétalas da quilha em geral lateralmente torcidas ou espiraladas e estilete barbado. A subtribo está representada no Paraná por 20 espécies (62\% das espécies que ocorrem no Brasil) e quatro gêneros, sendo Vigna Savi o mais diverso (12 espécies), seguido de Macroptilium (5), Phaseolus (2) e Lablab Adans. (1). Dentre estas espécies, Macroptilium atropurpureum é encontrada na condição subespontânea e Lablab purpureus, Phaseolus lunatus, $P$. vulgaris, Vigna umbellata e $V$. unguiculata são cultivadas. As espécies da subtribo encontram-se distribuídas por todo o Paraná, ocorrendo nos mais diversos ambientes, desde restinga, estepe e cerrado até habitats bastante úmidos, como margens de rios. O Paraná representa o limite sul de ocorrência no Brasil para três espécies.

\section{Chave de identificação para os gêneros de Phaseolinae no Paraná}

1. Plantas com tricomas uncinados; brácteas persistentes ao menos até a antese 3. Phaseolus

1'. Plantas sem tricomas uncinados; brácteas caducas.

2. Estípulas prolongadas abaixo do ponto de inserção. 4. Vigna

2'. Estípulas nunca prolongadas abaixo do ponto de inserção.

3. Asas mais longas que as outras pétalas, estandarte simétrico 2. Macroptilium

3'. Pétalas de tamanho semelhante, estandarte assimétrico.

4. Pétalas da quilha planas, formando um ângulo de aproximadamente $90^{\circ}$; legume oblongo 1. Lablab

4'. Pétalas da quilha cocleadas, espiraladas ou lateralmente torcidas; legume linear

4. Vigna

1. Lablab Adans., Fam. Pl. 2: 325. 1763.

1.1. Lablab purpureus (L.) Sweet, Hort. Brit. ed. 1: 481. 1827. Dolichos lablabL., Sp. Pl.: 725. 1753.

Fig. 1a-d

Subarbustos ou ervas, prostrados ou volúveis; tricomas uncinados ausentes. Estípulas 2-4 × 1-2,5 mm, lanceoladas ou triangulares, não expandidas abaixo do ponto de inserção, base truncada, persistentes; pecíolo 2,5-16 cm compr.; folíolos basais 3,5$12,5 \times 3-10,5 \mathrm{~cm}$, inteiros, assimétricos, deltóides a amplo-deltóides, ápice acuminado, base truncada a obtusa, folíolo terminal 5-12,5 ×4$11 \mathrm{~cm}$, inteiro, simétrico, amplo-trulado, ápice acuminado, base obtusa, ambas as faces glabras a pubérulas. Inflorescência $2-10,5 \mathrm{~cm}$ compr., glabrescente a pubérula, axilar ou terminal; brácteas caducas. Cálice campanulado, 4denteado, tubo 3,5-4,6 $\mathrm{mm}$ compr., pubérulo a pubescente externamente; corola branca a amarela; estandarte 11,7-16,5 × 5,3-18,5 mm, assimétrico, ápice retuso, 2 pares de apêndices basais e 1 par de calosidades medianas; asas 12,5$20 \times 7,5-11,5 \mathrm{~mm}$, orbiculares, esporão agudo; pétalas da quilha $15,5-26 \times 3,7-4,5 \mathrm{~mm}$, formando um ângulo de aprox. $90^{\circ}$; estames 11,5-23 mm compr.; ovário 4-9 × 1,2-1,6 mm, piloso em uma das margens; estilete $8-11,5 \mathrm{~mm}$, não prolongado além do ponto de inserção do estigma, persistente; estigma terminal. Legume 6-7 × 2-3 cm, oblongo, glabro; 1-2 sementes, 8-12 × 4,5-9 mm, borda superior e inferior convexas, brancas ou negras.

Material selecionado: Arapongas, 12.V.1985, fl. e fl., E.M. Hashimoto (FUEL 1023). Goioerê, 4.III.2006, fl. e fr., E.M. Silva (HCF 4076). Londrina, 28.VII.1987, fl. e fr., E.L. Maistro 785 (FUEL). Rolândia, 8.VI.1986, fl. e fl., A.R. Fontana (FUEL 2823). Ubiratã, 8.V.2005, fl. e fr., C.R. Ferreira (HCF 2359). 
Espécie nativa na África e cultivada em toda a região tropical (Maréchal et al. 1978). Segundo Lima (2010a) a espécie ocorre de forma subespontânea no Nordeste do Brasil. No Paraná foi coletada no norte e noroeste do estado, mas é provável que seja cultivada também em outras regiões.

Devido ser uma espécie cultivada no Paraná, a definição de seu estado de conservação não é aplicável (NA).

Lablab é um gênero monoespecífico e reconhecido pelas pétalas da quilha formando um ângulo de cerca de $90^{\circ}$ e pelo legume oblongo. Foi coletada com flores e frutos de março a julho.

2. Macroptilium (Benth.) Urb., Symb. Antill. 9: 457. 1928.

Subarbustos ou ervas, eretos, prostrados ou volúveis; tricomas uncinados ausentes; Estípulas não expandidas abaixo do ponto de inserção, base truncada, persistentes. Inflorescência axilar; brácteas caducas. Cálice 5-denteado; estandarte simétrico, com um par de apêndices basais e desprovido de calosidades medianas; asas consideravelmente mais longas que as outras pétalas; pétalas da quilha lateralmente torcidas; estilete nunca prolongado além da região estigmática, caduco; estigma terminal ou lateral. Legumes lineares a falcados.

Em várias análises filogenéticas com base em dados moleculares o gênero tem sido sustentado como monofilético (Delgado-Salinas et al. 1993; 2006; Espert et al. 2007). Macroptilium é caracterizado principalmente pela ausência de tricomas uncinados, asas consideravelmente maiores que o estandarte e pétalas da quilha lateralmente torcidas. É constituído por cerca de 17 espécies, com distribuição exclusiva no continente americano, concentrado na região tropical (Schrire 2005). No Brasil estão presentes 12 espécies (Moura 2010).

No Paraná ocorrem cinco espécies de Macroptilium: $M$. atropurpureum, $M$. bracteatum, M. erythroloma, $M$. lathyroides e $M$. prostratum. O gênero encontra-se distribuído em todo o estado.

\section{Chave de identificação para as espécies do gênero Macroptilium no Paraná}

1. Folíolos simétricos.

2. Estandarte com calos prolongados no sentido da base da unguícula, papilas ausentes na região dos calos; corola vermelha ou roxa 2.4. M. lathyroides

2'. Estandarte com calos prolongados para o centro, papilas proeminentes na região dos calos do estandarte; corola amarela com estrias vermelhas nas alas 2.5. M. prostratum

1'. Folíolos assimétricos

3. Papilas proeminentes na região dos calos do estandarte; frutos com até $4 \mathrm{~cm}$ compr.

3'. Papilas do estandarte ausentes; frutos com mais de $6 \mathrm{~cm}$ compr.

4. Bractéolas menores que o tubo do cálice; pedúnculo geralmente não estipitado.

......................................................................... 2.1. M. atropurpureum

4'. Bractéolas muito maiores que o tubo do cálice; pedúnculo estipitado ..... 2.2. M. bracteatum

2.1. Macroptilium atropurpureum (Moq. \& Sessé ex DC.) Urb., Symb. Antill. 9: 457. 1928. Phaseolus atropurpureus Moq. \& Sessé ex DC., Prod. 2: 395. 1825.

Fig. 1e-f, 5a

Ervas prostradas ou volúveis. Estípulas 2,5$5,3 \times 0,8-2,6 \mathrm{~mm}$, lanceoladas a ovais; pecíolo 1$7,7 \mathrm{~cm}$ compr.; folíolos basais $1,5-6 \times 1-4,5 \mathrm{~cm}$, lobados, assimétricos, ovais, ápice arredondado, agudo a acuminado, base truncada a obtusa, folíolo terminal 2-6,5 × 1-4 cm, inteiro ou lobado, simétrico, oval ou trulado, ápice retuso, agudo a acuminado, base retusa ou obtusa, face adaxial pubérula a serícea, abaxial velutina. Inflorescência 13-30 cm compr., pubérula a velutina; pedúnculo estipitado ou não, estípite 0,5-3,5 mm compr.; bractéolas 2,3-5 mm compr. Cálice tubuloso, tubo 3,5-5,6 mm compr., seríceo externamente; corola atropurpúrea; estandarte, 13-16,5 × 4,5-11,5 mm, ápice retuso, calos prolongados no sentido da base da unguícula, papilas ausentes na região dos 

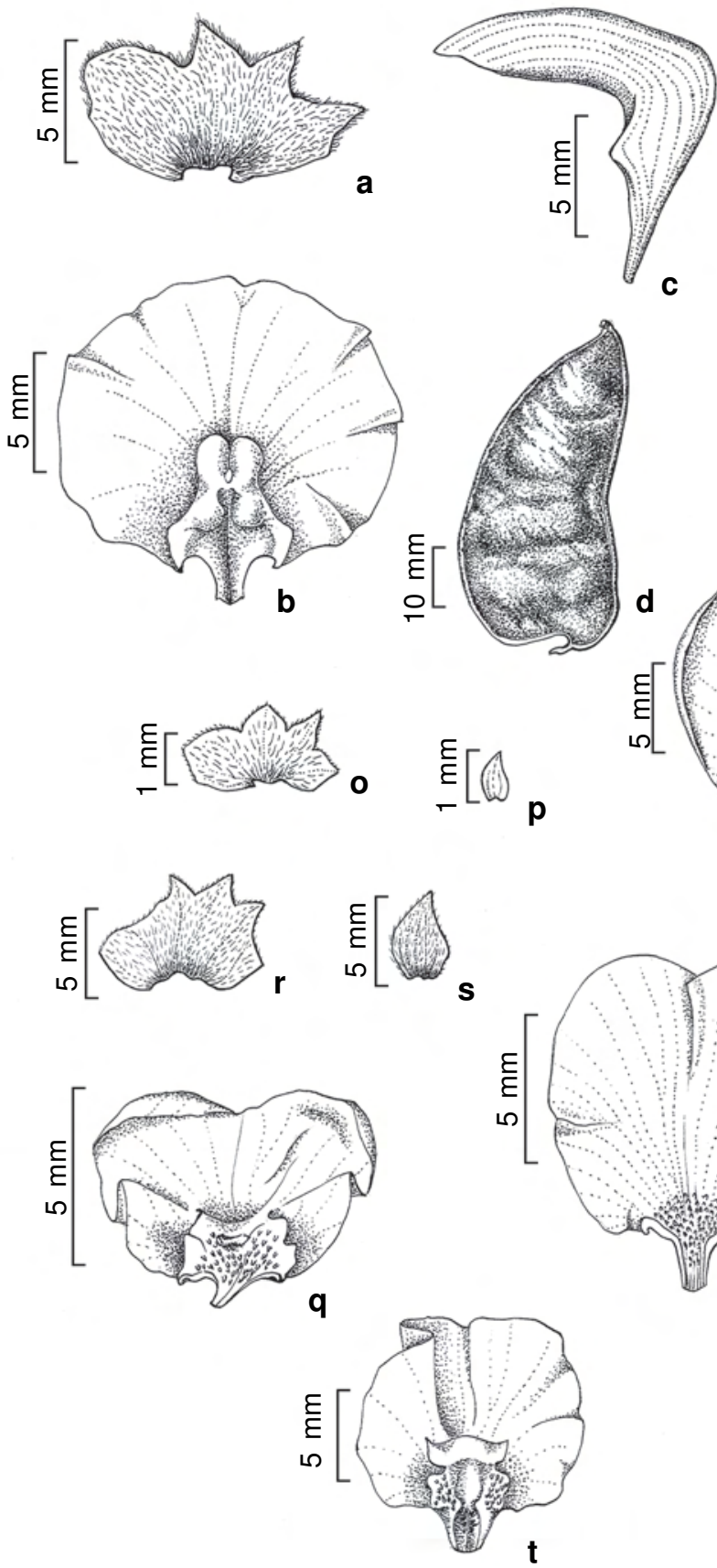

$\mathbf{s}$

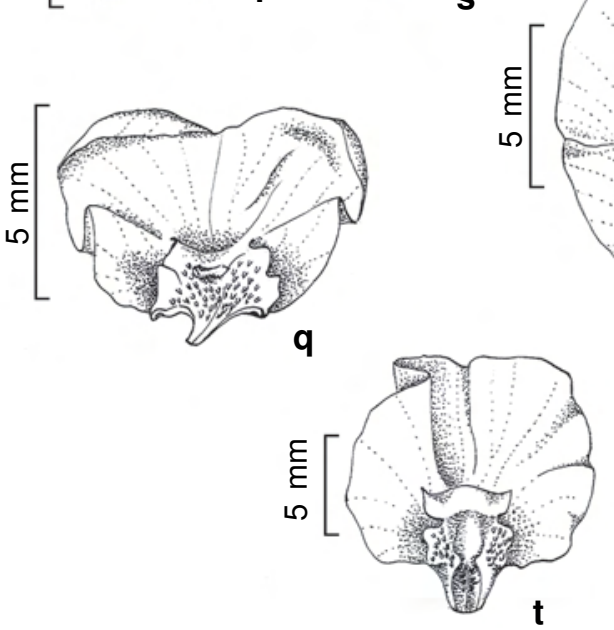

$a^{2}$
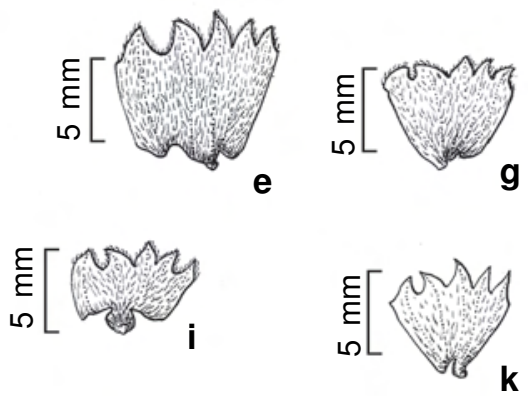

$\mathbf{k}$

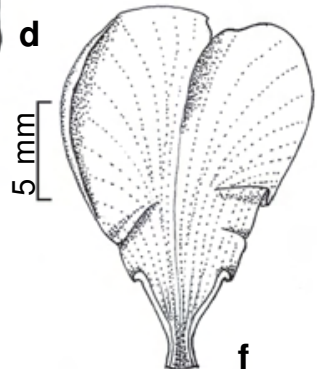

m
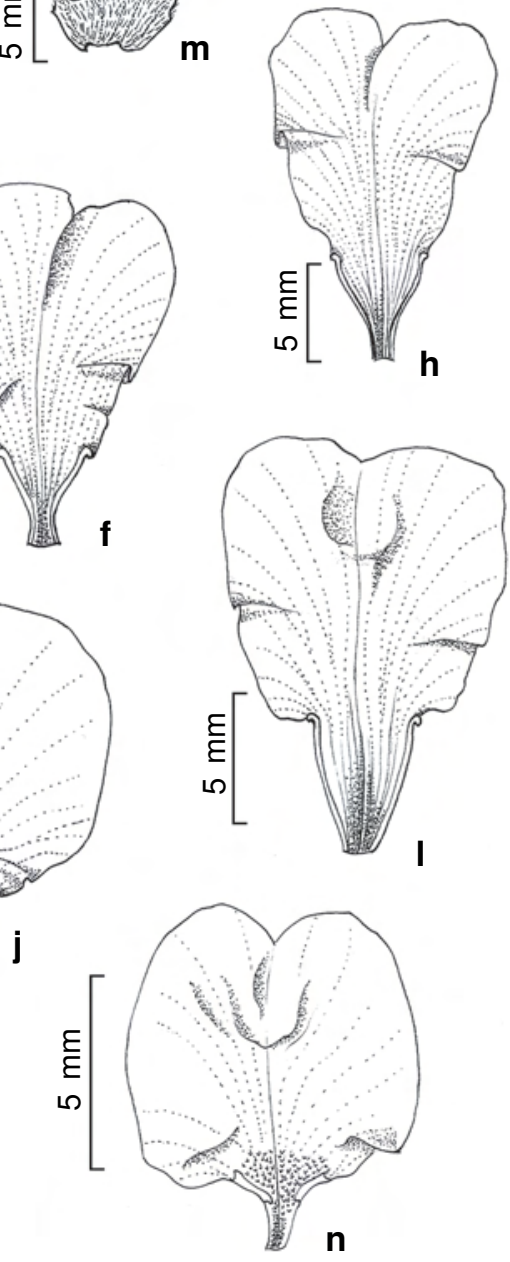

Figura 1 - a-d. Lablab purpureus (C.R. Ferreira s.n. HCF 2359) - a. cálice; b. estandarte; c. pétalas da quilha; d. fruto. e-f. M. atropurpureum (C. Snak 248) - e. cálice; f. estandarte. g-h. M. bracteatum (J. Carneiro 984) - g. cálice; h. estandarte. i-j. M. erythroloma (C. Snak 465) - i. cálice; j. estandarte. k-1. M. lathyroides (C. Snak 250) - k. cálice; 1. estandarte. m-n. M. prostratum (C. Kozera 2610) - m. cálice; n. estandarte. o-q. Phaseolus lunatus (G. Hatschabach 8104) - o. cálice; p. bractéola; q. estandarte. r-t. P. vulgaris (C. Snak 262) - r. cálice; s. bractéola; t. estandarte.

Figure 1 -a-d. Lablab purpureus - a. calyx; b. standard; c.keel petals; d. fruit. e-f. M. atropurpureum - e. calyx; f. standard. g-h. M. bracteatum - g. calyx; h. standard. i-j. M. erythroloma - i. calyx; j. standard. k-1. M. lathyroides - k. calyx; 1. standard. m-n. M. prostratum - m. calyx; n. standard. o-q. Phaseolus lunatus - o. calyx; p. bracteole; q. standard. r-t. P. vulgaris - r. calyx; s. bracteole; t. standard. 
calos; asas 17,5-23,5 × 7-14 mm, orbiculares, esporão arredondado; pétalas da quilha 11,5-14,5 $\times 2-3,2 \mathrm{~mm}$; estames $14-19,5 \mathrm{~mm}$ compr.; ovário 6-11 × 0,5-2 mm, piloso; estilete 6,5-10,5 mm compr.; estigma terminal. Legume 6,5-9 $\times 0,3-0,5 \mathrm{~cm}$, seríceo; 7-12 sementes, 3,7-4×2,4-2,7 mm, borda superior reta e inferior reta a convexa, de cor castanha com manchas negras.

Material selecionado: Campina Grande do Sul, 15.III.1990, fl. e fr., O.S. Ribas \& J.M. Silva 292 (C, MBM). Campo Mourão, 25.XI.2003, fl., M.G. Caxambú 215 (HCF, MBM). Jandaia do Sul, 10.IV.2009, fl., P.H.L. Ramos (HCF 7857). Londrina, 7.X.2009, fl. e fr., C. Snak et al. 249 (UPCB). Lupionópolis, 10.VI.2005, fl. e fr., J.S. Carneiro et al. 365 (FUEL). Marilena, 20.V.2008, fl., R.S. Garcia et al. 23 (HUEM). Mariluz, 16.IV.2002, fl., R.L.C. Bortoluzzi \& E. Biondo 1253 (MBM). Maringá, 6.X.2009, fl. e fr., C. Snak et al. 248 (UPCB). Morretes, 2.III.1983, fl., Y.S. Kuniyoshi 4635 (MBM). Paranaguá, 2.IX.1999, fl., J.M. Cruz et al. 184(MBM). Pitangueiras, 6.XI.1986, fl., S. Goetzke 44 (MBM). Porto Rico, 13.VIII.2010, fl. e fr., K. Kawakita et al.1328 (HUEM). Sertanópolis, 29.IX.1995, fl. e fr., M.C. Dias et al. 35 (FUEL). Tuneiras do Oeste, 26.I.2006, fl., V.M. Corneli 19 (HCF).

Espécie com local de origem incerto, mas Piper (1926) citou-o para a América Central. No Brasil a espécie já atingiu a condição de subespontânea, sendo encontrada nos estados da BA, DF, GO, MG, MS, MT, PA, PR, RJ e SP (Moreira 1997; Moura 2010). No Paraná, M. atropurpureum está presente em quase todo o Estado e foi confirmada a sua condição de subespontânea.

Devido ser uma espécie cultivada no Paraná, a definição de seu estado de conservação não é aplicável (NA).

Macroptilium atropurpureum caracteriza-se pelos folíolos geralmente lobados e pedúnculo da inflorescência raramente estipitado ou, quando estipitado, com fascículo de brácteas pouco denso. Esta espécie é frequentemente confundida com $M$. bracteatum, na qual o pedúnculo é estipitado, mas com fascículo de brácteas denso e bractéolas muito maiores que o tubo do cálice. Difere de M. erythroloma pela ausência de papilas proeminentes na região dos calos do estandarte, legumes maiores que $6 \mathrm{~cm}$ de compr. (vs. menores que $3,5 \mathrm{~cm}$ compr.) e pela cor da corola (atropurpúrea $v s$. alaranjada a avermelhada). Espécie coletada com flores e frutos durante o ano todo.
2.2. Macroptilium bracteatum (Nees \& Mart.) Maréchal \& Baudet, Bull. Jard Bot. Belg. 44: 443. 1974. Phaseolus bracteatus Nees \& Mart., Nov. Act. Nat. Cur. 12: 27. 1824. Fig. 1g-h

Ervas prostradas ou volúveis. Estípulas 5,57,5 × 2,7-3,5 mm, ovais; pecíolo 1,8-3 cm compr.; folíolos basais $2-4 \times 1,2-2,5 \mathrm{~cm}$, lobados, assimétricos, ovais, ápice arredondado, agudo a acuminado, base obtusa, folíolo terminal 2,5-4 $\times$ $1,7-3 \mathrm{~cm}$, inteiro ou lobado, simétrico, oval, ápice arredondado, agudo a acuminado, base obtusa, face adaxial serícea, abaxial velutina. Inflorescência 10$23 \mathrm{~cm}$ compr.; pubérula; pedúnculo estipitado, estípite 2-10 mm compr.; bractéolas 7-17 mm compr. Cálice tubuloso, 3-4,5 mm compr., hirsuto externamente; corola roxa a vinácea; estandarte 13$16,5 \times 9-11,5 \mathrm{~mm}$, ápice emarginado, calos prolongados para a base da unguícula, papilas ausentes na região dos calos; asas 25,5-27 × 10,5$11,5 \mathrm{~mm}$, esporão arredondado; pétalas da quilha 10-14,7 ×2,7-3,2 mm; estames 17,5-18 mm compr.; ovário 4,3-4,8 ×0,4-0,7 mm, seríceo; estilete 9,5$10,5 \mathrm{~mm}$ compr.; estigma terminal. Legume 6,5-8,5 $\times 0,5-0,7 \mathrm{~cm}$, seríceo; $17-19$ sementes, 2,9-3,2 $\times$ 2,8-3,1 mm, borda superior reta a côncava, inferior convexa, de cor castanha com manchas negras.

Material selecionado: Londrina, 18.V.1985, fl. e fr., E.G. Gaudens (UEC 37538). Maringá, 15.IV.1988, fl. e fr., S. Hirata (HUEM 1273). Porto Rico, 02.X.2008, fl. e fr., K.K. Kita et al. 875 (HUEM). Ribeirão do Pinhal, 27.X.2000, fl. e fr., J. Cordeiro 984 (MBM).

Espécie ocorrente na Argentina, Brasile Paraguai (Maréchal et al. 1978). No Brasil é encontrada nos estados da BA, CE, MG, MS, PB, PE, PI, SP e RJ (Barbosa-Fevereiro 1987; Moreira 1997; Moura 2010). No Paraná $M$. bracteatum foi encontrada no norte, onde predomina a floresta estacional semidecidual, sendo o estado o limite austral de ocorrência da espécie no Brasil.

Devido ter sido encontrada em apenas quatro localidades no estado a espécie e considerada como em perigo (EN).

Macroptilium bracteatum é morfologicamente reconhecida pelas bractéolas muito maiores que o tubo do cálice, característica principal para diferenciá-la de M. atropurpureum e de M. erythroloma. Espécie encontrada com flores e frutos de abril até outubro.

2.3. Macroptilium erythroloma (Mart. ex Benth.) Urb., Symb. Antill. 9: 457. 1928. Phaseolus erythroloma Mart. ex Benth., Comm. Leg. Gen.: 77. 1837. Fig. 1i-j, 5b

Ervas prostradas ou volúveis. Estípulas 4$8,5 \times 2,4-3,3 \mathrm{~mm}$, lanceoladas a ovais; pecíolo 1,5- 
4,5 cm compr.; folíolos basais 2,3-5 × 1,4-3,8 cm, inteiros ou lobados, assimétricos, ovais a amploovais ou oblongos, ápice arredondado, agudo a acuminado, base retusa ou obtusa, folíolo terminal 2,5-6 × 1,4-3,5 cm, inteiro ou lobado, simétrico, lanceolado a oval ou trulado, ápice arredondado a obtuso, base obtusa, face adaxial serícea ou hirsuta, abaxial velutina. Inflorescência 7-32 cm compr., pubérula a hirsuta; pedúnculo estipitado, estípite 2,3-14,5 mm compr.; bractéolas 3-9 mm compr. Cálice tubuloso, tubo 2-3,1 mm compr., seríceo ou hirsuto externamente; corola alaranjada a avermelhada; estandarte 8-10,5 × 6-8,5 mm, ápice retuso, calos prolongados no sentido da base da unguícula, papilas proeminentes na região dos calos; asas 12 $18 \times 6-7,5 \mathrm{~mm}$, arredondadas, esporão obtuso; pétalas da quilha 8,5-10 × 1,5-2,5 mm; estames 10,5$12,5 \mathrm{~mm}$ compr.; ovário $2,6-5 \times 0,6-1 \mathrm{~mm}$, pubérulo a piloso; estilete 6-8 $\mathrm{mm}$ compr.; estigma terminal. Legume 2,5-3,5 ×0,3-0,4 cm, seríceo ou hirsuto; 68 sementes, $2,3-3 \times 2-2,3 \mathrm{~mm}$, borda superior reta a convexa e inferior convexa, de cor castanha com manchas negras.

Material selecionado: Bocaiúva do Sul, 23.III.1983, fl., G. Hatschbach 46655 (MBM). Campo do Tenente, 25.I.1968, fl. e fr., G. Hatschbach \& C. Koczicki 18464 (MBM, UC, UPCB). Campo Mourão, 28.III.2010, fl. e fr., C. Snak et al. 465 (UPCB). Carambeí, 23.II.2006, fl. e fr., S.T.S. Miotto 2385 (ICN). Cerro Azul, 27.I.1970, fl., G. Hatschbach \& O. Guimarães 23418 (MBM, UC). Colombo, 14.III.1984, fl., A. Bidá et al. 382 (UPCB). Curitiba, 15.III.2006, fl. e fr., A.C. Cervi et al. 9096 (UPCB). Foz do Iguaçu, 3.II.1988, fl. e fr., Acildo 943 (MBM). Guairá, 7.IV.1961, fl. e fr., G. Hatschbach 8071 (MBM). Guarapuava, 13.II.1969, fl., G. Hatschbach 21152 (MBM, UC). Jaguariaíva, 22.III.1982, fl. e fr., G. Hatschbach 44811 (MBM). Lapa, 22.II.2006, fr., S.T.S. Miotto 2362 (ICN). Palmeira, 3.II.1999, fr., J.M. Cruz et al. 52 (MBM). Piraquara, 13.XII.1971, fl. e fr., G. Hatschbach 28485 (MBM, UC). Ponta Grossa, 25.XII.1977, fr., L. Krieger (UEC 69639). Rio Branco do Sul, 12.II.1967, fl. e fr., $G$. Hatschbach 16154 (C, MBM, UC, UPCB). Sengés, 12.XII.1910, fl., P. Dusén 11037 (E). Serrinha, 2.I.1915, fl., P. Dusén 16254 (GH, UC). Tibagí, 20.II.1953, fl., G. Hatschbach 3025 (MBM). Tijucas do Sul, 10.I.1992, fl., O.S. Ribas \& J. Cordeiro 450 (MBM).

Espécie nativa na América do Sul (BarbosaFevereiro 1987). No Brasil é encontrada nos estados da BA, DF, GO, MG, MS, MT, PR, RJ, RS, SC e SP (Barbosa-Fevereiro 1987; Moreira 1997; Moura 2010). No Paraná é encontrada em todo o estado.

Devido ser relativamente comum e amplamente distribuída no Paraná a espécie é considerada como sendo de preocupação menor (LC), em relação ao estado de conservação.
Macroptilium erythroloma pode ser reconhecida pelos folíolos lobados, papilas proeminentes na região dos calos do estandarte e legumes menores que $4 \mathrm{~cm}$ de compr. As duas últimas características a distinguem de $M$. atropurpureum e $M$. bracteatum. Indivíduos coletados com flores e frutos de dezembro a maio.

2.4. Macroptilium lathyroides (L.) Urb., Symb. Antill. 9: 457. 1928. Phaseolus lathyroides L., Sp. Pl. ed 2: 1018. 1763. Fig. $1 \mathrm{k}-1,5 \mathrm{c}$

Subarbustos eretos. Estípulas 4-6 × 0,8$1,2 \mathrm{~mm}$, linear-triangulares ou lanceoladas; pecíolo $1,5-3 \mathrm{~cm}$ compr.; folíolos basais 1,5-4,5×0,4-1 cm, folíolo terminal 1,5-6×0,3-1 cm, inteiros, simétricos, estreito-elípticos, estreito-oblongos ou lanceolados, ápice arredondado a agudo, base arredondada a obtusa, face adaxial glabra, abaxial glabrescente a serícea. Inflorescência 12-22 cm compr., glabrescente a pubérula; pedúnculo não estipitado; bractéolas 1,5-6,5 mm compr. Cálice tubuloso, tubo 4,5-5 mm compr., glabrescente a esparso-seríceo externamente; corola vermelha a arroxeada; estandarte 17-17,3 $\times$ 9,5-10,5 mm, ápice emarginado, calos prolongados no sentido da base da unguícula, papilas ausentes na região dos calos; asas 25-27,5 × 14,5-16 mm, orbiculares, esporão arredondado a obtuso; pétalas da quilha 13,5-16,5 × 2,5-3,3 mm; estames 15,518 mm compr.; ovário 7,3-10,5 ×0,7-0,9 mm, seríceo; estilete 9-9,5 mm compr.; estigma terminal. Legume 6-10×0,3-0,4 cm, seríceo; $13-25$ sementes, 3-3,2× $1,8-2 \mathrm{~mm}$, borda superior e inferior paralelas, de cor castanha ou castanha com manchas negras.

Material selecionado: Campo Mourão, 5.XII.2003, fl., A.E. Bianek 145 (HCF, MBM). Londrina, 7.X.2009, fl. e fr., C. Snak et al. 250 (UPCB).

Espécie encontrada em toda a América tropical (Maréchal et al. 1978). No Brasil está presente nos estados de AL, AM, BA, CE, DF, ES, GO, MA, MS, MG, MT, PA, PB, PE, PR, RJ, RS e SP (Barbosa-Fevereiro 1987; Moreira 1997; Fortunato et al. 2008a; Moura 2010). No Paraná é encontrada no norte e noroeste, onde predomina a Floresta Estacional Semidecidual.

Devido ser encontrada em apenas três localidades no Estado, a espécie é considerada como em perigo (EN), com relação ao estado de conservação.

Macroptilium lathyroides é caracterizada pelo hábito ereto, estandarte com calos prolongados no sentido da base da unguícula e papilas ausentes na região dos calos. Indivíduos florescem e frutificam de outubro a março. 
2.5. Macroptilium prostratum (Benth.) Urb., Symb. Antill. 9: 457. 1928. Phaseolus prostratus Benth., Fl. bras. 15(1): 192. 1859.

Fig. $1 \mathrm{~m}-\mathrm{n}$

Ervas prostradas. Estípulas 2,8-6,4 × 0,8$1,7 \mathrm{~mm}$, lanceoladas ou triangulares; pecíolo 2 $12,5 \mathrm{~cm}$ compr.; folíolos basais $2,5-7 \times 0,8-2 \mathrm{~cm}$, inteiros, simétricos, estreito-elípticos a elípticos ou lanceolados, ápice arredondado a agudo, base retusa, arredondada a obtusa, folíolo terminal 2,5$7,5 \times 0,5-2,5 \mathrm{~cm}$, inteiro, simétrico, estreito-elíptico, lanceolado a oval, ápice arredondado, obtuso a agudo, base retusa, arredondada ou obtusa, ambas as faces glabrescentes a pubérulas. Inflorescência 7-27 cm compr., pubérula a hirsuta; pedúnculo não estipitado; bractéolas 1,2-2,6 mm compr. Cálice tubuloso, tubo 2-2,8 $\mathrm{mm}$ compr., pubescente externamente; corola amarela com estrias vermelhas nas alas; estandarte 6,5-9,5 × 5,5-7,5 mm, ápice retuso a emarginado, calos prolongados para o centro do estandarte, papilas proeminentes na região dos calos; asas 9-14×3-8 mm, orbiculares, esporão arredondado; pétalas da quilha 6-8,7 × 1,5$3 \mathrm{~mm}$; estames 6-10,5 mm compr.; ovário 2-3,5 ×0,5$1 \mathrm{~mm}$, pubescente; estilete 4,5-7 mm compr.; estigma terminal. Legume 1,9-2,2 ×0,3-0,4 cm, híspido; 2-4 sementes, ca. $2,6 \times 2,1 \mathrm{~mm}$, borda superior e inferior convexas, de cor castanha.

Material selecionado: Arapoti, 23.X.1961, fl., G. Hatschbach 8565 (MBM). Balsa Nova, 21.XI.2005, fl. e fr., C. Kozera \& O.P. Kozera 2610 (MBM, UPCB). Lapa, 4.XI.1964, fl., J. Mattos 11938 (SP). Palmeira, 12.XI.1985, fl., R. Kummrow \& S. Graham 2648 (C, MBM). Ponta Grossa, 9.X.2000, fl., K. Dalazoana et al. (HUPG 14704). Porto Amazonas, 17.XII.1929, fl., Gurgel (RB 59407). São Mateus do Sul, 1.IX.1985, fl., L.F. Pereira (FUEL 1733, UEC 46604). Serrinha, 9.XII.1908, fl., P. Dusén 7340 (BM, E).

Espécie ocorre na Argentina, Bolívia, Brasil, Paraguai e Uruguai (Barbosa-Fevereiro 1987). No Brasil está presente nos estados de GO, MG, MS, PR, RS, SC e SP (Barbosa-Fevereiro 1987; Moreira 1997; Moura 2010). No Paraná sua distribuição é restrita ao Segundo Planalto, principalmente em vegetação de estepe e cerrado.
Devido ter sido coletada em diversas localidades e possuir uma área de ocupação maior que $2.000 \mathrm{~km}^{2}$, a espécie é considerada, em relação ao estado de conservação, como de preocupação menor (LC).

A combinação de hábito herbáceo, folíolos simétricos e estandarte com os calos prolongados em direção ao centro da pétala, e com papilas proeminentes entre eles, distingue Macroptilium prostratum das demais espécies do gênero. Coletada com flores e frutos entre outubro e fevereiro.

\section{Phaseolus L., Sp. Pl. 2: 723. 1753.}

Subarbustos, ervas eretas ou volúveis; tricomas uncinados presentes. Estípulas não expandidas abaixo do ponto de inserção, base truncada, persistentes Inflorescência pseudoracemosa, axilar; brácteas persistentes ao menos até a antese. Cálice 4-5-denteado; estandarte simétrico; pétalas da quilha cocleadas, 1,5 voltas; estilete nunca prolongado além do ponto de inserção do estigma, caduco; estigma terminal. Legume linear.

Phaseolus atualmente é um táxon bem delimitado, monofilético, apresentando como sinapomorfias a presença de tricomas uncinados, ausência de nectários extraflorais na raque da inflorescência, brácteas florais de primeira ordem persistentes e pétalas da quilha espiraladas lateralmente (cocleadas). Apesar disso, a relação de Phaseolus com os demais gêneros de Phaseolinae ainda é incerta (Delgado-Salinas et al. 1993; 1999; 2006). É constituído por cerca de 60 espécies com distribuição exclusiva na América, estando presente nas regiões tropical, subtropical e temperada (Schrire 2005). No Brasil estão presentes apenas duas espécies nativas (Lima 2010b).

No Paraná Phaseolus está representado por duas espécies cultivadas: P. lunatus e P. vulgaris. Tais espécies são cultivadas em todo o estado, devido à sua importância na alimentação humana.

\section{Chave de identificação para as espécies do gênero Phaseolus no Paraná}

1. Bractéolas menores que o tubo do cálice, estandarte piloso externamente 3.1. P. lunatus

1'. Bractéolas maiores que o tubo do cálice, estandarte glabro externamente 3.2. P. vulgaris 
3.1. Phaseolus lunatus L., Sp. Pl. 2: 724. 1753.

Fig. 1o-q

Ervas volúveis. Estípulas 2-2,4 ×0,8-1 mm, lanceoladas; pecíolo 2-9,5 cm compr.; folíolos basais 3,5-6,5 × 2,5-5 cm, inteiros, assimétricos, ovais, ápice agudo a acuminado, base obtusa, folíolo terminal 3,5-10,4 × 2,5-7 cm, inteiro, simétrico, oval, trulado a amplo-trulado, ápice agudo a acuminado, base obtusa, face adaxial glabra a glabrescente, abaxial glabrescente. Inflorescência 1,5-14 cm compr., pubescente; bractéolas 1-3 $\times$ $0,5-0,8 \mathrm{~mm}$, lanceoladas a ovais. Cálice campanulado, 4-denteado, tubo 1,6-1,9 mm compr., seríceo externamente; corola amarela ou lilás; estandarte 5,9-6,2 ×6,7-7 mm, ápice retuso, 1 par de apêndices basais e 1 espessamento mediano, piloso externamente; asas 8,3-9,3 × 3,5-3,7 mm, alongadas, esporão obtuso; pétalas da quilha 5,8$7 \times 1,8-2,2 \mathrm{~mm}$; estames 8,7-9 mm compr.; ovário 2,5-5 × 1-1,2 mm, pubescente; estilete 5,6-7 mm compr. Legume 3,5 $\times 0,7 \mathrm{~cm}$, glabro; 4 sementes, 12,3-16,0 × 8,4-10 mm, borda superior côncava e inferior convexa, de cor creme.

Material selecionado: Cerro Azul, 26.IX.1961, fl. e fr., G. Hatshcbach 8104 (MBM, UC, UPCB). Curitiba, X.1980, fl. e fr., V.C. Lima (UPCB 11352). Loanda, 8.IV.1959, fl., G. Hatshcbach 5895 (MBM).

Espécie presente em toda a América tropical (Maréchal et al. 1978). Lima (2010b) considerou a espécie como subespontânea nos estados de MG, MS, PR, RJ e SP. Porém no Paraná só foram coletados espécimes em cultivo.

Devido à espécie ser cultivada no Paraná, o estado de conservação não é aplicável (NA).

Phaseolus lunatus é reconhecida pelas bractéolas menores que o tubo do cálice e estandarte piloso na face externa. Coletada com flores em abril e com flores e frutos em outubro e novembro.

\subsection{Phaseolus vulgaris L., Sp. Pl. 2: 723. 1753.}

Fig. 1r-t

Subarbustos ou ervas volúveis. Estípulas 3 $5 \times 1-3 \mathrm{~mm}$, lanceoladas a ovais; pecíolo 2,5-18 cm compr.; folíolos basais 2-13,5 ×1,5-11,5 cm, inteiros, assimétricos, ovais, ápice acuminado, base obtusa, folíolo terminal $2,5-14,5 \times 2-12 \mathrm{~cm}$, inteiro, simétrico, oval a amplo-oval, ápice acuminado, base obtusa, ambas as faces glabrescentes a esparso-estrigosas. Inflorescência 1-6 cm compr.; bractéolas 4-6,7 × 2,5-4 mm, ovais. Cálice campanulado, 4-denteado, tubo 1,3-3,5 $\mathrm{mm}$ compr., glabro a glabrescente externamente; corola branca, amarela, rosada a lilás; estandarte 9-13 $\times$
7,5-12 mm, ápice retuso a emarginado, 1 par de apêndices basais e 1 espessamento mediano, glabro externamente; asas 10,5-15,5 × 5-7 mm, orbiculares, esporão arredondado a obtuso; pétalas da quilha 8,3-12,3 × 1,5-4 mm; estames 11,2-17,4 mm compr.; ovário 4,2-8 8 0,5-1,8 mm, pubescente; estilete $8-11,5 \mathrm{~mm}$. Legume 8,5-11 $\times 0,8-1,1 \mathrm{~cm}$, pubérulo; 4-7 sementes, $0,9-1,1 \times$ 0,4-0,6 mm, borda superior côncava e inferior convexa, de cor castanha ou negra.

Material selecionado: Cascavel, 17.I.2010, fl. e fr., $C$. Snak \& T. Snak 307 (UPCB). Curitiba, 28.I.1975, fl., L.F. Ferreira 161 (MBM). Guamiranga, 27.X.2002, fl. e fr., A. Vedon (HUPG 11354). Guaratuba, 23.XI.1974, fl., G. Hatschbach 35524 (MBM). Lapa, 8.XII.974, fl., G. Hatschbach 35587 (MBM). Lidianópolis, 18.III.2006, fl., M.N. Silva (HCF, MBM). Londrina, 23.XI.1985, fl. e fr., J.M. Diniz (FUEL 1512). Ponta Grossa, 27.XII.1981, fl., $L$. Krieger 19269 (CESJ).

Phaseolus vulgaris é amplamente cultivada em todo o mundo e, por este motivo, existem centenas de variedades e cultivares. Segundo Maréchal et al. (1978) as formas selvagens da espécie ocorreriam ao longo da Cordilheira dos Andes até o norte da Argentina, entre 1.500 e 2.800 metros de altitude. No Paraná não existem muitas coletas da espécie, mas ela é cultivada ao longo de todo o estado, o qual destaca-se como o maior produtor de feijão do Brasil (Lollato et al. 2001).

Devido à espécie ser cultivada no Paraná, seu estado de conservação não é aplicável (NA).

Phaseolus vulgaris caracteriza-se pelas bractéolas maiores que o tubo do cálice e estandarte glabro na face externa. Coletada com flores e frutos de outubro a março.

4. Vigna Savi, Nuov. Giorn. Lett. ser. 3. 8: 113. 1824. Arbustos, subarbustos ou ervas, eretos, prostrados ou volúveis; tricomas uncinados ausentes. Estípulas expandidas abaixo do ponto de inserção ou não, base truncada, triangular ou auriculada, persistentes. Inflorescência pseudoracemosa, axilar; brácteas caducas. Cálice 4-5-denteado; pétalas de tamanho semelhante; estandarte simétrico ou assimétrico; pétalas da quilha planas, cocleadas, espiraladas ou lateralmente torcidas; estilete prolongado além do ponto de inserção do estigma ou não, caduco; estigma terminal ou lateral. Legume linear a falcado.

Vigna Savi é um grupo que passou por diversas mudanças no século passado, quando várias espécies, dos gêneros Phaseolus e 
Dolichos L., foram transferidas para esse gênero, e o que era um dos menores gêneros do grupo passou a ser o mais numeroso dentre as Phaseolinae. Ainda é um grupo a ser resolvido, pois é polifilético (Delgado-Salinas et al. 1993). Caracteriza-se pela ausência de tricomas uncinados, estípulas geralmente expandidas abaixo do ponto de inserção, com a base auriculada ou triangular, eixo secundário da inflorescência reduzido a duas protuberâncias glandulosas, brácteas florais caducas, nunca mais que duas flores por nodosidade, pétalas de tamanho semelhante, estilete caduco, geralmente prolongado além da região estigmática. Porém, estas características não são suficientes para isolar por completo o gênero (Maréchal et al. 1978). O gênero é constituído por cerca de 104 espécies, com distribuição pantropical (Schrire 2005). No Brasil são encontradas 16 espécies (Perez 2010).

Vigna está representado no Paraná por 12 espécies: $V$. adenantha, $V$. candida, $V$. caracalla, V. lasiocarpa, $V$. linearis, $V$. longifolia, V. luteola, V. peduncularis, V. sp., $V$. speciosa, $V$. umbellata e $V$. unguiculata. As espécies encontram-se distribuídas ao longo de todo o estado.

Não foi confirmada no presente estudo a ocorrência de Vigna vexillata (L.) A. Rich, citada por Perez (2010) para o Paraná.

\section{Chave de identificação para as espécies do gênero Vigna no Paraná}

1. Estípulas não expandidas abaixo do ponto de inserção, com base truncada.

2. Pétalas da quilha lateralmente torcidas.

3. Estilete prolongado além da região estigmática.

4. Estandarte sem um par de calosidades como continuação dos apêndices basais; legumes com até $5 \mathrm{~cm}$ compr. 4.8. V. peduncularis

4'. Estandarte com um par de calosidades como continuação dos apêndices basais; legumes com mais de $7 \mathrm{~cm}$ compr. 4.9. V.sp.

3'. Estilete nunca prolongado além da região estigmática.

5. Cálice campanulado; estigma terminal 4.10. V. speciosa

5'. Cálice tubuloso; estigma oblíquo 4.2. V. candida

2'. Pétalas da quilha cocleadas ou espiraladas.

6. Pétalas da quilha cocleadas, com até 2 voltas

4.1. V. adenantha

6. Pétalas da quilha espiraladas, com mais de 2 voltas.

7. Estandarte levemente assimétrico; legumes com até $11 \mathrm{~cm}$ compr.; corola violácea .......

4.5. V. linearis

7'. Estandarte fortemente assimétrico; legumes com mais de $12 \mathrm{~cm}$ compr.; corola creme com uma mancha roxa nas alas 4.3. V. caracalla

1'. Estípulas expandidas abaixo do ponto de inserção, com base auriculada ou triangular.

8. Pétalas da quilha planas.

9. Estípulas com base auriculada; corola amarela; legumes com até $5,5 \mathrm{~cm}$ compr

4.7. V. luteola

9'. Estípulas com base triangular; corola lilás; legumes com mais de $25 \mathrm{~cm}$ compr.

4.12. V. unguiculata

8'. Pétalas da quilha lateralmente torcidas

10. Ervas eretas; estípula com base triangular; pétalas da quilha com apêndice

4.11. V. umbellata

10'. Ervas prostradas ou volúveis; estípula com base auriculada; pétalas da quilha sem apêndice

11. Porção basal da estípula com lobos iguais; estilete não prolongado além da região estigmática

11'. Porção basal da estípula com lobos desiguais; estilete prolongado além da região estigmática 
4.1. Vigna adenantha (G. Mey.) Maréchal, Mascherpa \& Stainier, Taxon 27: 202. 1978. Phaseolus adenanthus G. Mey., Prim. Fl. Esseq.: 239. 1818.

Figs. 2a-d, $4 \mathrm{~d}$

Ervas prostradas ou volúveis. Estípulas 34,5 × 1,7-2,5 mm, lanceoladas a ovais ou deltóides, não expandidas abaixo do ponto de inserção, base truncada; pecíolo 1,5-7 cm compr.; folíolos basais 3-8,5 × 1,5-6 cm, inteiros, assimétricos, ovais ou deltóides, ápice arredondado, obtuso a agudo, base truncada a obtusa, folíolo terminal 3-10,3 $\times$ 2,3-8 cm, inteiro, simétrico, oval, trulado ou deltóide, ápice obtuso a agudo, base truncada a obtusa, face adaxial glabrescente a velutina, abaxial pubérula a velutina. Inflorescência 3,2$13,3 \mathrm{~cm}$ compr., glabrescente a pubescente. Cálice campanulado, 4-denteado, tubo 2,5-5 mm compr., glabro a glabrescente externamente; corola branca com uma mancha roxa nas asas; estandarte 16,5$21 \times 17,7-25 \mathrm{~mm}$, assimétrico, ápice emarginado, 1 par de apêndices basais; asas 21,4-26,3 × 10$12,5 \mathrm{~mm}$, arredondada a orbicular, esporão obtuso; pétalas da quilha $27-47,5 \times 5-9,5 \mathrm{~mm}$, cocleadas, 2 voltas; estames $42-56 \mathrm{~mm}$ compr.; ovário 8$12,5 \times 1-1,3 \mathrm{~mm}$, pubérulo a pubescente; estilete 34,5-42 mm compr., não prolongado além da região estigmática; estigma terminal. Legume 7 $8 \times 0,7-1 \mathrm{~cm}$, glabro; 9-13 sementes, $6-7 \times 4,8-$ $5,3 \mathrm{~cm}$, borda superior côncava e inferior convexa, de cor castanha.

Material selecionado: Diamante do Norte, 07.IV.2002, fl. e fr., C. Rosa et al. 247 (HUEM). Guaratuba, 12.IV.1958, fl. e fr., G. Hatschbach 4474 (B, HB, MBM). Marilena, 1.VII.2008, fl. e fr., K.K. Kita et al. 751 (HUEM). Paranaguá, 22.IV.2010, fl. e fr., C. Snak \& J.M.T. Souza 500 (UPCB). Pontal do Paraná, 13.III.2010, fl., C. Snak et al. 365 (UPCB). Porto Rico, 2.VII.2008, fl. e fr., K.K. Kita et al. 799 (HUEM).

Espécie originária da América tropical e introduzida no Velho Mundo (Piper 1926). No Brasil é encontrada nos estados do AM, BA, DF, MG, MS, MT, PA, PR, RJ, RS, SP e TO (Moreira 1997; Perez 2010). No Paraná é encontrada no noroeste do estado, em restinga, próxima a cursos d'água.

Devido ter sido coletada em apenas 11 localidades no Paraná e sua área de ocupação ser pouco maior que $2,000 \mathrm{~km}^{2}$ é considerada como quase ameaçada (NT).

Vigna adenantha é distinta das demais espécies do gênero pelas pétalas da quilha cocleadas. Floresce e frutifica de março a maio e novembro.
4.2. Vigna candida (Vell.) Maréchal, Mascherpa \& Stainier, Taxon 27: 201. 1978. Phaseolus candidus Vell., Fl. Flum.: 311; 7:pl. 125. 1825. Figs. 2e-g, 4 e Ervas volúveis. Estípulas 1,5-3 ×0,8-2 mm, lanceoladas a ovais, não expandidas abaixo do ponto de inserção, base truncada; pecíolo $2-9 \mathrm{~cm}$ compr., folíolos basais 3,3-9 ×2,5-6,5 cm, inteiros ou lobados, simétricos ou assimétricos, ovais ou trulados, ápice agudo a acuminado, base truncada a obtusa, folíolo terminal 3,3-10,5 ×2-8 cm, inteiro, simétrico, trulado, ápice agudo a acuminado, base truncada a obtusa, face adaxial glabra a glabrescente, abaxial glabra a esparso-serícea. Inflorescência 4-25 cm compr., glabra a glabrescente. Cálice tubuloso, 4-denteado, tubo 3,5-7 mm compr., glabro a gabrescente externamente; corola branca a creme com uma mancha roxa nas asas; estandarte 30,5-40,5 × 29-34 mm, assimétrico, ápice retuso, 1 par de apêndices basais; asas 33-47 × 15-18 mm, alongadas, esporão obtuso a agudo; pétalas da quilha $27-35 \times 8-10 \mathrm{~mm}$, lateralmente torcidas; estames $33-46 \mathrm{~mm}$ compr.; ovário 11-17×1-1,7 mm, glabrescente a pubescente; estilete 24-37 mm compr., não prolongado além da região estigmática; estigma oblíquo. Legume 7,5$10,5 \times 0,3-0,4 \mathrm{~cm}$, glabro; 7-12 sementes, 4,3-6,4 $\times$ $1,5-2,2 \mathrm{~mm}$, borda superior e inferior paralelas, de cor castanha.

Material selecionado: Bocaiúva do Sul, 30.XII.1980, fl., $R$. Kummrow 1433 (GB, MA, MBM). Campo Largo, 3.I.1978, fl., G. Hatschbach 41077 (MBM). Campo Mourão, 29.III.2010, fl. e fr., C. Snak et al. 475 (UPCB). Cândido de Abreu, 13.XI.1986, fl., W.M. Kranz 24 (FUEL). Colombo, 22.II.2005, fl. e fr., R.F.S. Possette 179 (MBM). Curitiba, 19.XII.1995, fl., C. Kozera \& V.A. Dittrich 19 (NY, UPCB). Guarapuava, 15.IV.1964, fl. e fr., G. Hatschbach 11183 (MBM). Irati, 31.III.1983, fl., R. Kummrow \& L. Bohs 2266 (MBM). Ivaí, 24.III.1937, fl., G. Tessmann 6132 (GH, MBM, RB). Mangueirinha, 22.XI.1991, fl., H.R.S. Abrão \& A.J. Kostin 197 (MBM). Pinhão, 12.II.1996, fl. e fr., G. Tiepolo \& S.R. Ziller 268 (MBM). Piraquara, 22.II.1950, fl. e fr., G. Hatschbach 1891 (MBM). Rio Branco do Sul, 25.XI.1982, fl., P.I. Oliveira 698 (MBM). Ubiratã, 9.III.2009, fl. e fr., E.S. Sekine et al. 127 (HCF).

Ocorre na América do Sul até o Paraguai (Maréchal et al. 1978). No Brasil está presente nos estados da BA, CE, DF, ES, GO, MG, MS, MT, PA, PR, RJ, RS, SC e SP (Moreira 1997; Perez 2010). A espécie é encontrada em todo o Paraná, com exceção do norte do estado, em borda de mata.

Devido à espécie ser amplamente distribuída pelo estado, possuindo uma área de ocupação maior que $2.000 \mathrm{~km}^{2}$ é considerada como de preocupação menor (LC). 
Vigna candida é distinta por suas flores grandes, com cerca de $4 \mathrm{~cm}$ de comprimento, brancas a creme, com mancha roxa nas asas e pela margem da metade superior do estandarte involuta. Floresce de novembro a abril e frutifica de fevereiro a abril.

4.3. Vigna caracalla (L.) Verd., Kew Bull. 24:552. 1970. Phaseolus caracalla L., Sp. Pl. 2: 725. 1753.

Fig. 2h-k, $4 \mathrm{f}$

Ervas volúveis. Estípulas 2,5-5 × 1,5-3 mm, triangulares a deltóides, não expandidas abaixo do ponto de inserção, base truncada; pecíolo $5-15 \mathrm{~cm}$ compr.; folíolos basais 6-15,5 ×3-9,5 cm, inteiros, assimétricos, trulados, ovais a amplo-ovais, ápice agudo a acuminado, base truncada a obtusa, folíolo terminal 5-17 ×3-9 cm, inteiro, simétrico, trulado a amplo-trulado, ápice agudo a acuminado, base obtusa, face adaxial serícea, abaxial glabra a glabrescente. Inflorescência 6-26 cm compr., glabra a esparso-pilosa. Cálice tubuloso, 5-denteado, tubo 4,5-11,5 mm compr., glabro externamente; corola creme com uma mancha roxa nas alas; estandarte 21-40 × 13-22 mm, assimétrico, ápice retuso, 1 par de apêndices basais; asas 16,5-43,5 × 13-25,5 mm, alargadas, esporão arredondado; pétalas da quilha 20-93 ×5-17 mm, espiraladas, 2,5-6 voltas; estames 48-112 mm compr.; ovário 10,3-15 × 0,6-1,1 mm, glabrescente a pubescente; estilete 59-117 mm, não prolongado além da região estigmática; estigma terminal. Legume 13-20 $\times 0,7-1,2 \mathrm{~cm}$, glabro; $15-17$ sementes, $5,5 \times 5,6 \mathrm{~mm}$, borda superior reta e inferior convexa, de cor castanha.

Material selecionado: Adrianópolis, 5.IV.1976, fl., G. Hatschbach 38358 (MBM, MICH, MO). Antonina, 29.IV.2010, fl., J.M.T. Souza 01 (UPCB). Bocaiúva do Sul, 14.I.1969, fl., G. Hatschbach \& C. Koczicki 20731 (C, MBM, NY). Campina Grande do Sul, 18.II.1962, fl., G. Hatschbach 8937 (HUPG, MBM). Cascavel, 2.IV.2010, fl., C. Snak \& D.R. Snak 490(UPCB). Coronel Vivida, 20.II.1971, fl., G. Hatschbach 26376 (HB, MBM, MO). Dois Vizinhos, 11.VI.1968, fl., G. Hatschbach \& O. Guimarães 19369 (MBM). Foz do Iguaçu, 16.IV.2010, fl., A.F. Policena \& M.X. Silva 01 (UPCB). Guaratuba, 3.III.2006, fl., J.M. Silva \& J. Cordeiro 4715 (MBM). Ibipora, 26.V.1995, fr., M.C. Dias et al. (FUEL 18198). Londrina, 1.IV.2000, fl. W.M. Kranz 665 (FUEL). Mamboré, 16.V.1967, fl. e fr., J. Lindeman \& H. Haas 5324 (MBM). Maringá, 30.IV.1985, fl., J.M. Margarido et al. (HUEM 493). Primeiro de Maio, 20.IV.1999, fl., O.C. Pavão et al. (FUEL 24914). Prudentópolis, 11.IV.2003, fl., R. Goldenberg \& P.H. Labiak 599(HUPG, MBM, UPCB). São Miguel do Iguaçu, 27.III.1977, fl., $G$. Hatschbach 39862 (MBM). Sapopema, 16.V.1998, C. Medri et al. 611 (FUEL). Siqueira Campos, 28.III.1974, fl., R. Kummrow 476 (C, MBM). Tibagí, 30.III.1953, fl.,
G. Hatschbach 3249 (MBM). Tijucas do Sul, 23.I.1976, fl., R. Kummrow 1029 (MBM, MO, NY). Umuarama, 18.IV.1968, fl., G. Hatschbach \& O. Guimarães 19027 (C, F, HUPG, MBM, NY).

Ocorre nas Américas do Sul e Central (Maréchal et al. 1978). No Brasil está presente nos estados do AC, BA, DF, ES, GO, MG, MS, PA, PE, PR, RS e SC (Moreira 1997; Perez 2010). Ocorre em todo o Paraná, sendo encontrada na maioria das vezes em borda de mata.

Devido a espécie ser amplamente distribuída pelo Estado, possuindo uma área de ocupação maior que $2.000 \mathrm{~km}^{2}$, é considerada como de preocupação menor (LC).

Vigna caracalla é reconhecida pelo estandarte fortemente assimétrico e pelas pétalas da quilha várias vezes espiraladas, podendo ter até seis voltas. Floresce de janeiro a maio e frutifica em maio.

4.4. Vigna lasiocarpa (Mart. ex Benth.) Verdc., Kew Bull. 24: 539. 1970. Phaseolus lasiocarpus Mart. ex Benth., Comm. Leg. Gen.: 76. $1837 . \quad$ Figs. 2l-n

Ervas volúveis. Estípulas 4,5-9×0,5-2,5 mm, lineares a triangulares, expandidas abaixo do ponto de inserção, base auriculada, lobos desiguais; pecíolo 2,5-7,5 cm compr.; folíolos basais 4,5-6,5 ×3,5-6 cm, inteiros, assimétricos, ovais, ápice retuso ou obtuso, base truncada a obtusa, folíolo terminal 4,6-5,5 ×3,5$4,2 \mathrm{~cm}$, inteiro, simétrico, oval ou trulado, ápice retuso ou arredondado, base retusa ou obtusa, ambas as faces seríceas. Inflorescência 10-22 cm compr., pubescente. Cálice tubuloso, 5-denteado, tubo 3,24,3 mm compr., seríceo externamente; corola amarela; estandarte 31-33 × 35-36 mm, assimétrico, ápice fendado, 1 par de apêndices basais e 1 espessamento mediano; asas 25-27×15-17 mm, alongadas, esporão agudo; pétalas da quilha 15,5-21,3 × 4,4-6 mm, lateralmente torcidas; estames 31-34 mm compr.; ovário 5,7-7,5 × 1,3-1,6 mm, pubescente; estilete 26$28 \mathrm{~mm}$, prolongado além da região estigmática; estigma lateral interno. Legume 5,2-8 × 0,5-0,8 cm, lanuginoso; 11-14 sementes, 4,3-4,6×3-3,6 mm, borda superior reta e inferior convexa, de cor castanha.

Material selecionado: Campo Mourão, 7.II.1962, fl. e fr., G. Hatschbach 8969 (L, HB). Dois Vizinhos, 6.XII.1968, fl., G. Hatschbach \& O. Guimarães (MBM 8621).

Ocorre em toda a América tropical (Maréchal et al. 1978). No Brasil é encontrada nos estados do AM, AP, MS, MT, PA, PR, RO e RS (Moreira 1997; Fortunato et al. 2008b; Perez 2010). No Paraná está presente no oeste e noroeste, em regiões sob domínio de floresta estacional semidecidual, onde é encontrada próxima a cursos d'água. 

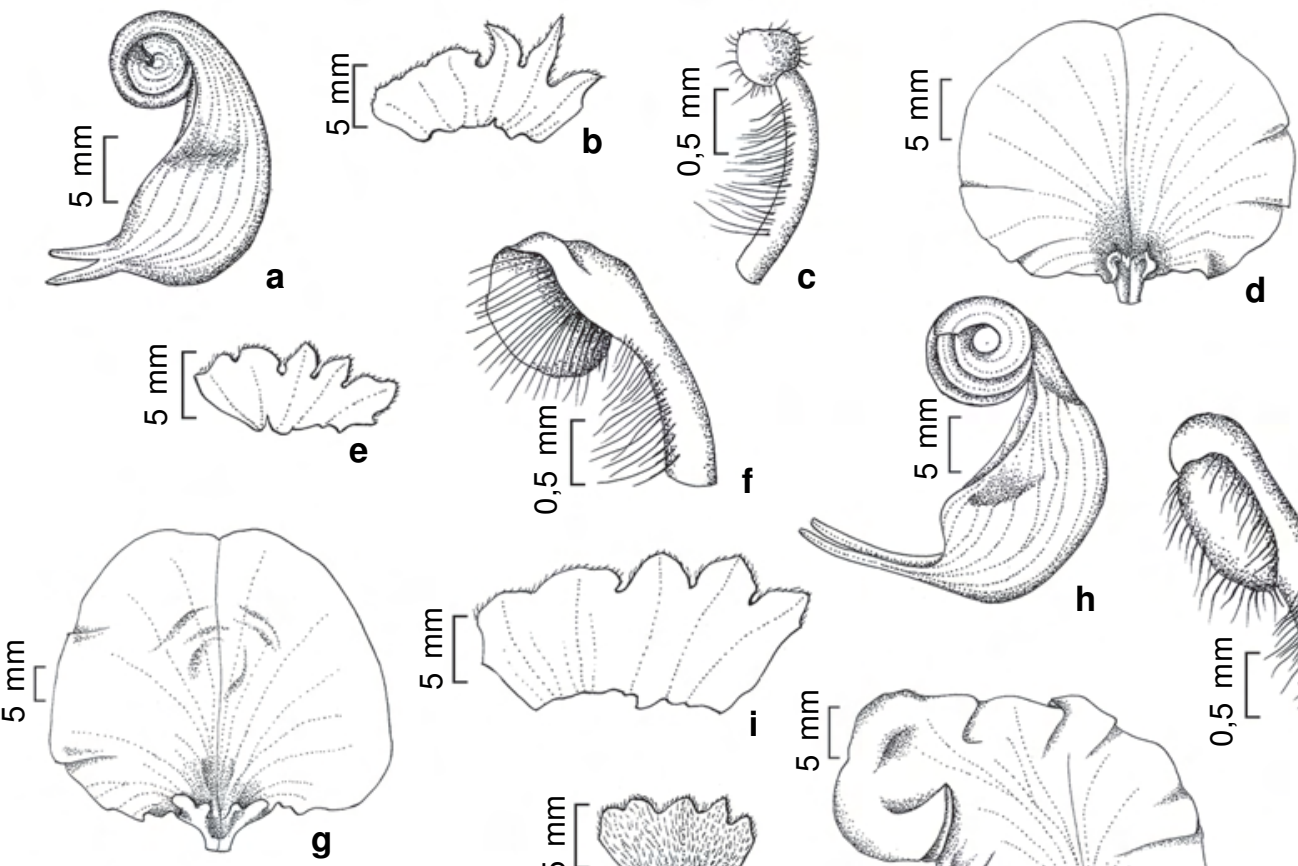

$\mathbf{h}$
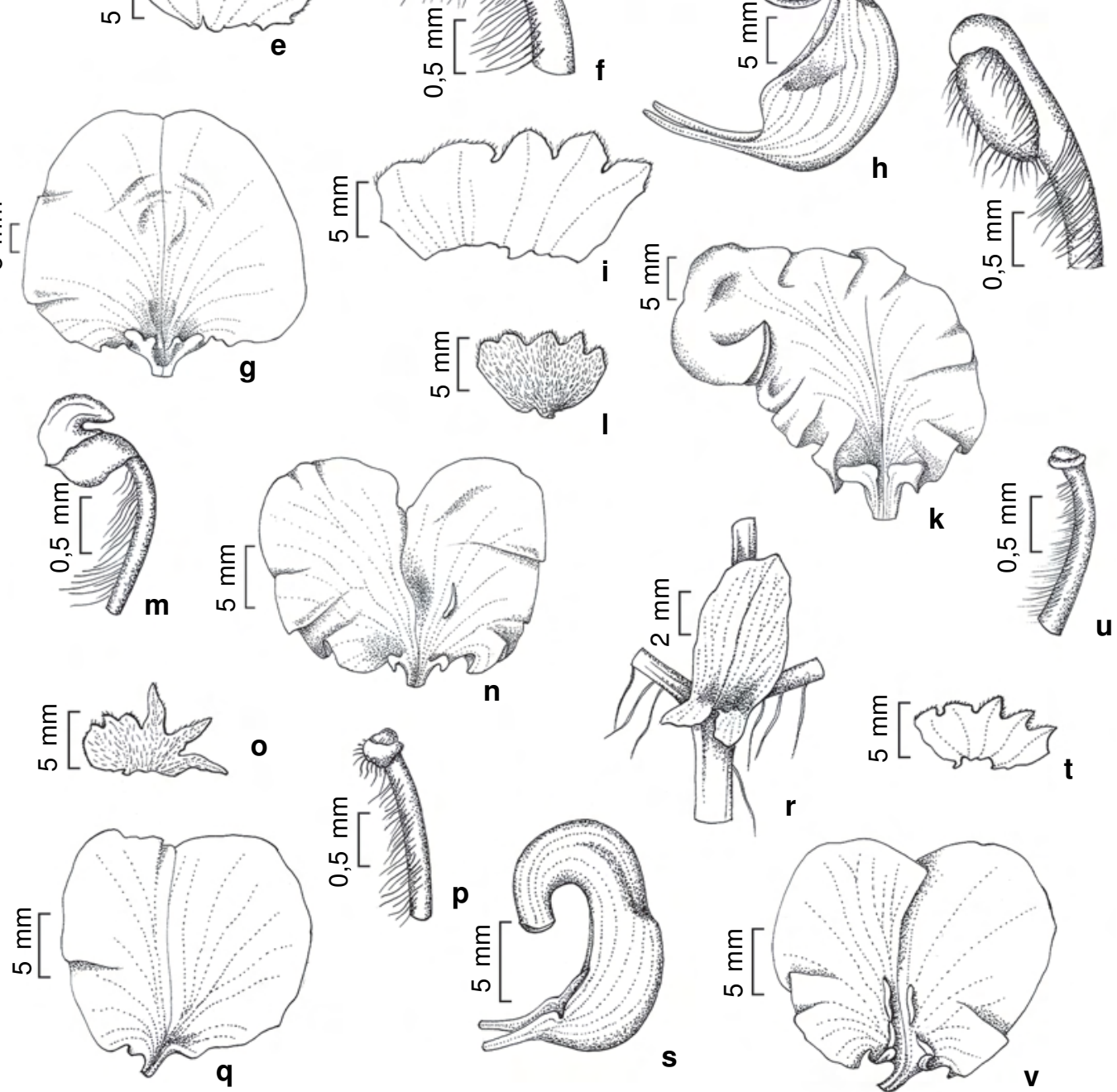

Figura 2 - a-d. Vigna adenantha - a. pétalas da quilha cocleadas; b. cálice; c. ápice do estilete e estigma; d. estandarte (C. Snak 365 ). e-g. V. candida - e. cálice; f. ápice do estilete e estigma; g. estandarte (C. Snak 475 ). h-k. V. caracalla - h. pétalas da quilha espiraladas; i. cálice; j. ápice do estilete e estigma; k. estandarte (C. Snak 490). 1-n. V. lasiocarpa - 1. cálice; m. ápice do estilete e estigma; n. estandarte (G. Hatschbach sn. MBM 8621). o-q. V. linearis - o. cálice; p. ápice do estilete e estigma; q. estandarte ( $R$. Kummrow 892). r-v. V. longifolia - r. estípulas com a base auriculada; s. pétalas da quilha lateralmente torcida; t. cálice; u. ápice do estilete e estigma; v. estandarte (C. Snak 269).

Figure 2 - a-d. Vigna adenantha - a. keel petals, cochleate; b. calyx; c. style apex and stigma; d. standard (C. Snak 365). e-g. V. candida - e. calyx; f. style apex and stigma; g. standard (C. Snak 475). h-k. V. caracalla - h. keel petals, spiraled; i. calyx; j. style apex and stigma; k. standard (C. Snak 490). 1-n. V. lasiocarpa - l. calyx; m. style apex and stigma; n. standard (G. Hatschbach sn. MBM 8621). o-q. V. linearis - o. calyx; p. style apex and stigma; q. standard (R. Kummrow 892). r-v. V. longifolia - r. stipules with base auriculate; s. keel petals, laterally curved; t. calyx; u. style apex and stigma; v. standard (C. Snak 269). 
Devido a espécie ter sido coletada em apenas duas localidades no Estado e possuir uma área de ocupação menor que $10 \mathrm{~km}^{2}$ é considerada como criticamente em perigo (CR).

Vigna lasiocarpa é reconhecida pela base da estípula auriculada com lobos desiguais e indumento seríceo. Comumente confundida com $V$. longifolia, da qual se distingue pelo estilete prolongado além da região estigmática. Floresce em dezembro e fevereiro e frutifica em fevereiro.

4.5. Vigna linearis (Kunth) Maréchal, Mascherpa \& Stainier, Taxon 27: 202. 1978. Phaseolus linearis Kunth, Nov. Gen. Sp. 6: 445. 1824 . Figs. 2o-q, 4g Ervas prostradas ou volúveis. Estípulas 2,74×1,3-2 mm, lanceoladas a ovais, não expandidas abaixo do ponto de inserção, base truncada; pecíolo $1-5,5 \mathrm{~cm}$ compr.; folíolos basais $2-7 \times 0,5-3 \mathrm{~cm}$, inteiros ou lobados, simétricos ou assimétricos, lanceolados a ovais, ápice obtuso a agudo, base retusa, arredondada ou obtusa, folíolo terminal 2$6,8 \times 0,3-2 \mathrm{~cm}$, inteiro, simétrico, lanceolado a oval, ápice obtuso a agudo, base arredondada ou obtusa, ambas as faces glabras a esparso-seríceas. Inflorescência 4-24 cm compr., esparso-pilosa a pilosa. Cálice campanulado, 4-denteado, tubo 2,33,7 mm compr., seríceo ou piloso externamente; corola violácea; estandarte $15-24 \times 12-22 \mathrm{~mm}$, assimétrico, ápice emarginado, 1 par de apêndices basais; asas 17-30 ×6-11 mm, alongadas, esporão arredondado a obtuso; pétalas da quilha 30-43 × 3 $6 \mathrm{~mm}$, espiraladas, 2-2,5 voltas; estames $37-55 \mathrm{~mm}$ compr.; ovário 7,5-13,5 × 0,5-1,1 mm, pubérulo a pubescente; estilete $20-42 \mathrm{~mm}$, não prolongado além da região estigmática; estigma terminal. Legume 6,5-10,5 $\times 0,4-0,6 \mathrm{~cm}$, glabro; 4-7 sementes, $4 \times 4 \mathrm{~mm}$, borda superior côncava e inferior convexa, de cor castanha.

Material selecionado: Balsa Nova, 14.II.2006, fl., $C$. Kozera \& O.P. Kozera 3020 (UPCB). Campo do Tenente, 25.I.1968, fl., G. Hatschbach \& C. Kiczicki 18454 (F, MBM). Colombo, 14.II.1975, fl., R. Kummrow 892 (MBM). Curitiba, 28.I.1972, fl., N. Imaguire 3163 (MBM). Guarapuava, 13.II.1969, fl., G. Hatschbach 21176 (C, F, MBM). Imbituva, 5.III.1982, fl., $R$. Kummrow et al. 1864 (MBM). Palmeira, 11.VIII.1988, fl., S. Ginsbarg et al. 677 (LL, UPCB). Piraquara, 6.II.1971, fl., G. Hatschabach 26295 (MBM). Ponta Grossa, 28.X.1964, fl., L. Dombrowski 690 (MBM). Porto Amazonas, 13.III.1988, fl., R. Kummrow \& F. Grifo 3029 (MBM). Rio Branco do Sul, 14.II.1967, fl., L. Dombrowski 2472 (MBM). São José dos Pinhais, 6.II.1970, fl., G. Hatschbach 23462 (MBM). Tibagí, 30.III.1953, fr., G. Hatschbach 3120 (MBM).
Distribui-se em toda a América tropical (Maréchal et al. 1978). No Brasil é encontrada nos estados do AM, AC, AP, DF, GO, MG, MS, MT, RO, PA, PR, RJ e SP (Moreira 1997; Perez 2010). No Paraná é encontrada principalmente em estepe, cerrado, borda de mata e vegetação secundária.

Devido à espécie ser amplamente distribuída pelo Estado, possuindo uma área de ocupação maior que $2.000 \mathrm{~km}^{2}$, é considerada como de preocupação menor (LC).

Vigna linearis é caracterizada pelas pétalas da quilha espiraladas com mais de duas voltas completas e estandarte levemente assimétrico. Frequentemente confundida com $V$. peduncularis, na qual as pétalas da quilha são lateralmente torcidas. Floresce de novembro a março e agosto e frutifica em março.

4.6. Vigna longifolia (Benth.) Verdc., Kew Bull. 24: 541. 1970. Phaseolus longifolius Benth., Comm. Leg. Gen.: 75. 1837. Figs. 2r-v, $4 \mathrm{~h}$

Ervas prostradas ou volúveis. Estípulas 5-9,5 $\times 1,7-4 \mathrm{~mm}$ lanceoladas a ovais, expandidas abaixo do ponto de inserção, base auriculada, lobos iguais; pecíolo $0,7-6,4 \mathrm{~cm}$ compr.; folíolos basais $2-5 \times 2-$ $3 \mathrm{~cm}$, inteiros, simétricos ou assimétricos, lanceolados a ovais, ápice obtuso a agudo, base arredondada, folíolo terminal 1,5-5×1-2,5 cm, inteiro, simétrico, lanceolado a oval, ápice obtuso a agudo, base arredondada, ambas as faces glabras a glabrescentes. Inflorescência 2-12,5 cm compr., glabra a hirsuta. Cálice campanulado, 5-denteado, tubo 1,5-3,2 mm compr., glabro a glabrescente externamente; corola amarela a alaranjada; estandarte 14-22 × 13-23 mm, assimétrico, ápice fendido, 1 par de apêndices basais e 1 par de calosidades mediana; asas 14-22 $\times 7-15 \mathrm{~mm}$, alargadas, esporão arredondado a obtuso; pétalas da quilha 14-23 × 3-15 mm, lateralmente torcidas; estames 15-32 mm compr.; ovário 4,7-8×0,9-1,2 mm, piloso; estilete 18-22 mm compr., não prolongado além da região estigmática; estigma terminal. Legume 2,7-5,3 $\times 0,5-0,7 \mathrm{~cm}$, lanuginoso; 7-10 sementes, $2,8-3,6 \times 2,6-2,8 \mathrm{~mm}$, borda superior reta e inferior convexa, de cor castanha com manchas negras.

Material selecionado: Guaraqueçaba, 20.III.2010, fl. e fr., C. Snak et al. 397(UPCB). Guaratuba, 3.I.1912, fl., P. Dusén 13527 (E). Matinhos, 11.XII.1942, fl., Pe. J. Moure 422 (MBM, SP). Paranaguá, 30.XI.2009, fl. e fr., C. Snak et al. 269 (UPCB). Pontal do Paraná, 20.I.1996, fl., O.S. Ribas et al. 1036 (MBM).

Ocorre na América do Sul e Antilhas (Maréchal et al. 1978). No Brasil é encontrada nos estados do AM, MG, MS, PA, PR, RJ, RS e SP 
(Moreira 1997; Perez 2010). No Paraná ocorre no litoral, em ambientes de restinga, principalmente próximo a cursos d'água.

Devido à espécie ter sido coletada em apenas cinco localidades, e hoje estar restrita apenas às Ilhas do Mel e de Superaguii é considerada com em perigo (EN).

Vigna longifolia é distinta pelas estípulas com base auriculada com lobos iguais, corola amarela a alaranjada, pétalas da quilha lateralmente torcidas e estigma terminal. Frequentemente confundida com $V$. lasiocarpa, da qual difere pelo estilete não prolongado além da região estigmática. Floresce e frutifica entre novembro e maio.

4.7. Vigna luteola (Jacq.) Benth., in Mart. Fl. bras. 15(1): 194. 1859. Dolichos luteolus Jacq., Hort. Bot. Vindob. 1:39.1770.

Figs. 3a-d, 4 i

Ervas prostradas ou volúveis. Estípulas 2,6-4,7 $\times 0,6-1,3 \mathrm{~mm}$, lanceoladas, expandidas abaixo do ponto de inserção, base auriculada, lobos iguais; pecíolo 0,9-6,5 cm compr.; folíolos basais 2,5-5,5×1-3,5 cm, inteiros, simétricos, lanceolados a ovais, ápice arredondado, agudo a acuminado, base obtusa ou cuneada, folíolo terminal 3-7,5 × 1-4 cm, inteiro, simétrico, lanceolado a oval, ápice arredondado, agudo a acuminado base obtusa ou cuneada, ambas as faces glabras a glabrescentes. Inflorescência 1-14 cm compr., glabra a pilosa. Cálice campanulado, 4denteado, tubo 2-3,5 mm compr., glabro a glabrescente externamente; corola amarela; estandarte 11-15×14 $20 \mathrm{~mm}$, simétrico, ápice retuso a emarginado, 1 par de apêndices basais; asas 12-15 × 5-8 mm, alongadas a arredondadas, esporão agudo; pétalas da quilha 11-13 × 5,5-8 mm, planas; estames 12-20,5 mm compr.; ovário 4-7,6 × 0,6-1 mm, esparso-piloso a piloso; estilete 7,5-12 mm compr., prolongado além da região estigmática; estigma lateral interno. Legume $3-5 \times 0,3-0,7 \mathrm{~cm}$, piloso ou seríceo; $4-10$ sementes, $3,5-4,7 \times 2,7-4 \mathrm{~mm}$, borda superior reta a côncava e inferior convexa, de cor castanha a enegrecida.

Material selecionado: Campo Largo, 16.II.2006, fl., J.M. Silva 4697 (MBM). Curitiba, 25.II.2010, fl. e fr, C. Snak \& J. Meirelles 345 (UPCB). Guaraqueçaba, fl. e fr, C. Snak et al. 393 (UPCB). Guaratuba, 17.XII.1998, fl., M. Borgo et al. 313 (UPCB). Matinhos, 13.III.2010, fl. e fr, C. Snak et al. 363 (UPCB). Paranaguá, 30.XI.2009, fl. e fr, C. Snak et al. 268 (UPCB). Pontal do Paraná, 13.III.2010, fl. e fr., C. Snak et al. 366 (UPCB).

Espécie mais comum e amplamente distribuída do gênero, ocorrendo em toda a região tropical (Maréchal et al. 1978). No Brasil está presente nos estados do AM, BA, DF, MG, MT, PA, PI, PR, RJ,
RO, RS e SP (Moreira 1997; Perez 2010). No Paraná é encontrada no Primeiro Planalto, em restinga, onde está restrita às regiões úmidas próximas aos rios.

Devido à espécie estar presente em diversas localidades e possuir uma área de ocupação maior que $2.000 \mathrm{~km}^{2}$ apresenta preocupação menor (LC).

Vigna luteola é caracterizada pela base da estípula auriculada, pétalas da quilha planas e estilete prolongado além da região estigmática. Confundida com $V$. longifolia, cujas pétalas da quilha são lateralmente torcidas. Floresce e frutifica durante o ano todo, exceto em agosto e setembro.

4.8. Vigna peduncularis (Kunth) Fawc. \& Rendle, Fl. Jamaica 4: 68. 1920. Phaseolus peduncularis Kunth, Nov. Gen. Sp. 6: 447. $1823 . \quad$ Figs. 3e-i, 4j

Ervas prostradas ou volúveis. Estípulas 2$3,5 \times 1,5-2,5 \mathrm{~mm}$, lanceoladas a amplo-ovais, não expandidas abaixo do ponto de inserção, base truncada; pecíolo 1-10 cm compr.; folíolos basais $1,5-6,5 \times 0,5-4 \mathrm{~cm}$, inteiros, assimétricos, lanceolados a ovais ou oblongos, ápice obtuso, agudo a acuminado, base retusa ou obtusa, folíolo terminal 2,3-6 $\times 0,3-3,5 \mathrm{~cm}$, inteiro, simétrico, linear a oval, ápice obtuso, agudo a acuminado, base retusa ou obtusa, ambas as faces glabras a glabrescentes. Inflorescência 2-22 cm compr., glabra a glabrescente. Cálice campanulado, 4-denteado, tubo 3-4 mm compr., glabro a glabrescente externamente; corola violácea; estandarte 12-20×11-20 mm, assimétrico, ápice retuso, 1 par de apêndices basais, auriculas proeminentes; asas 14-24 × 4,3-7 mm, alongadas, esporão arredondado a obtuso; pétalas da quilha 13-16 × 4-4,7 mm, lateralmente torcidas; estames 17 -25 mm compr.; ovário 5,5-7,5 × 0,8-1,3 mm, pubescente; estilete 9-16 mm compr., prolongado além da região estigmática; estigma lateral externo. Legume 3,5-4,5 ×0,5 cm, pubérulo; 7-9 sementes, $3-3,7 \times 1,8-2,2 \mathrm{~mm}$, borda superior e inferior paralelas, de cor castanha.

Material selecionado: Campo Mourão, 28.III.2010, fl., C. Snak et al. 461 (UPCB). Curitiba, 22.XII.1971, fl., G. Hatschabach 28555 (MBM, MICH, MO). Lapa, 12.II.1967, fl., G. Hatschbach 15966 (MBM). Laranjeiras do Sul, 12.II.1969, fl., G. Hatschbach 21140 (C, MBM). Palmeira, 28.II.1992, fl., J.M. Silva \& P. Ruas 1078 (C, MBM). Pinhão, 15.II.1990, fl. e fr., W.M. Kranz 579 (FUEL). Piraquara, 28.II.1946, fl., N. Imaguire 213 (MBM). Ponta Grossa, 20.II.2003, fl., O.S. Ribas et al. 5038 (MBM). São Jerônimo da Serra, 24.II.1957, fl., $G$. Hatschbach 3609 (MBM). São José dos Pinhais, 4.III.1980, fl., G. Hatschbach 42783 (MBM). Tibagí, 22.II.1953, fl. e fr., G. Hatschbach 3020 (MBM). 

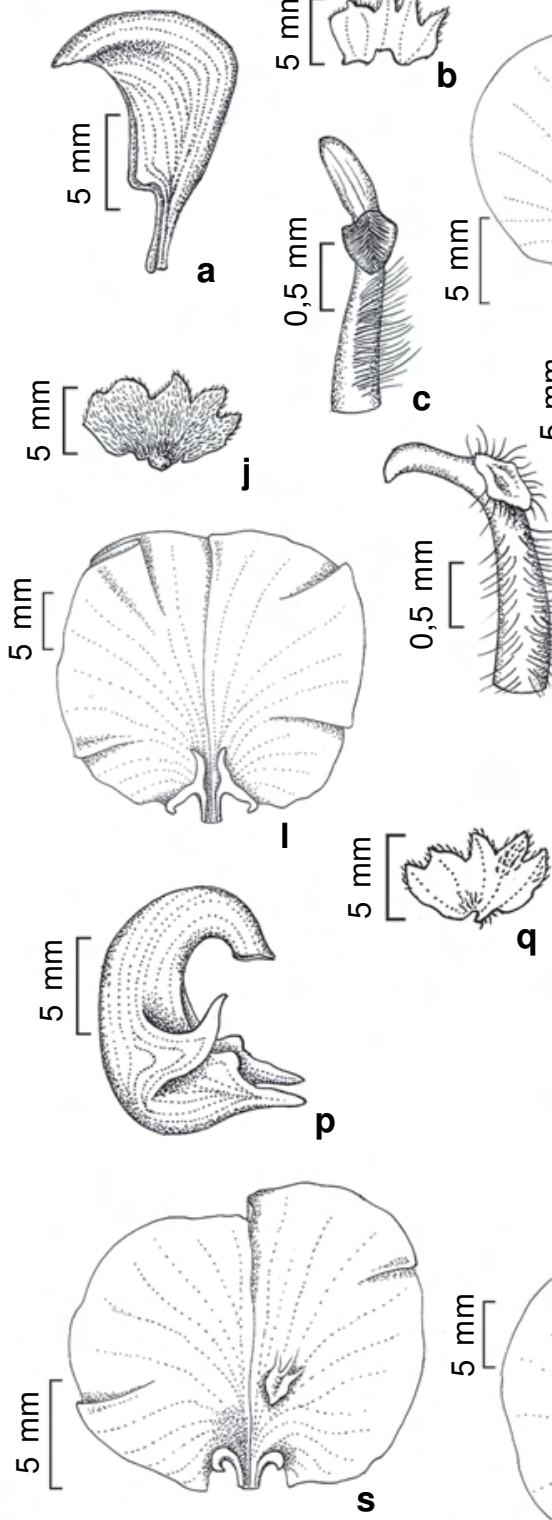
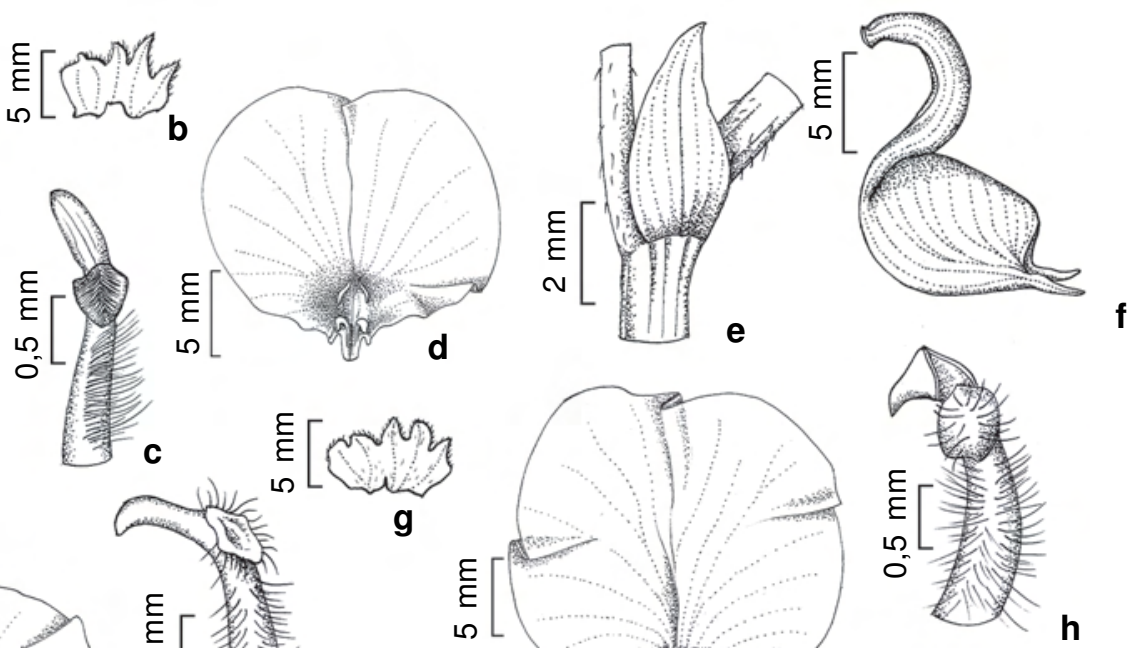

h
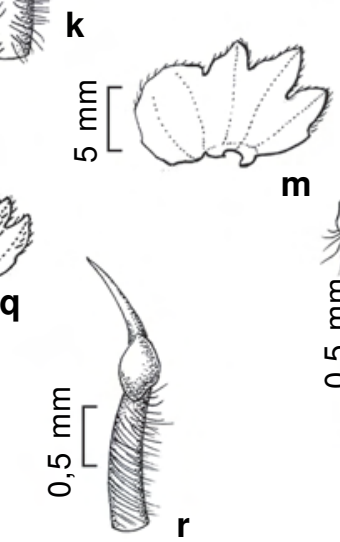

m
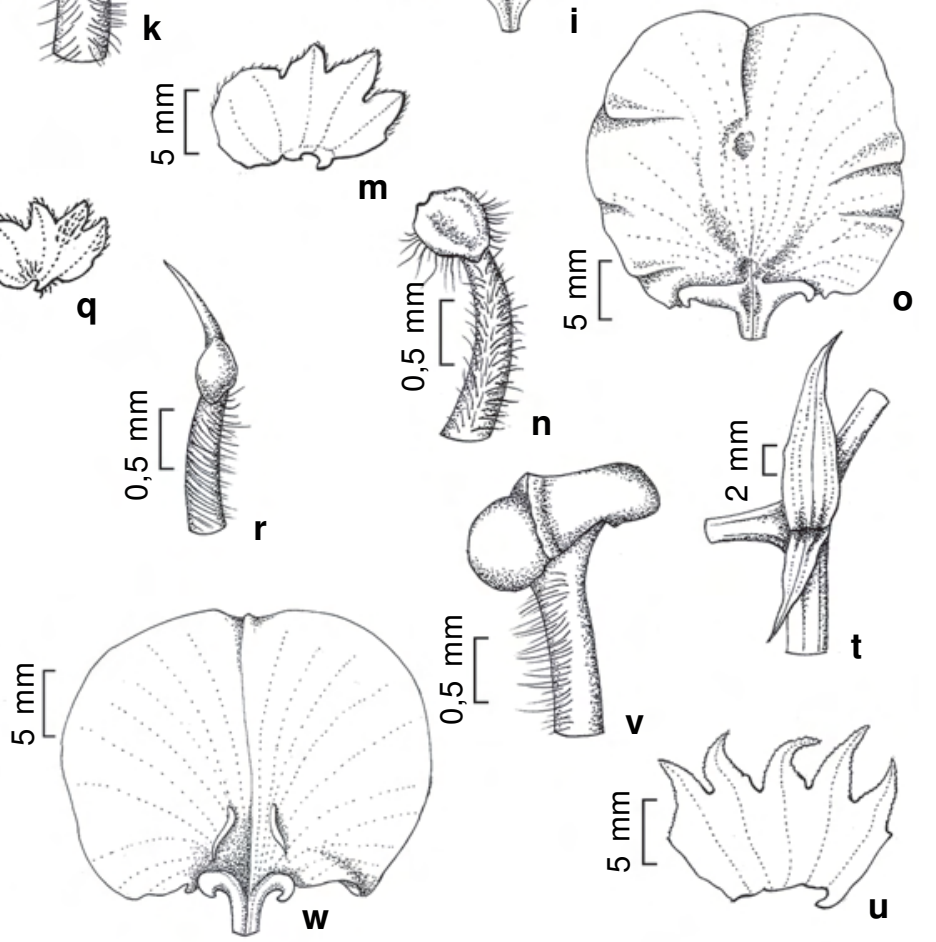

Figura 3 - a-d. Vigna luteola - a. pétalas da quilha plana; b. cálice; c. ápice do estilete e estigma; d. estandarte (C. Snak 268). e-i. V. peduncularis - e. estípula com a base truncada; f. pétalas da quilha lateralmente torcida; g. cálice; h. ápice do estilete e estigma; i. estandarte (C. Snak 461).j-1. Vigna sp - j. cálice; k. ápice do estilete e estigma; 1. estandarte (J. Cordeiro 1129). m-o. V. speciosa-m. cálice; n. ápice do estilete e estigma; o. estandarte (C. Snak 296). p-s. V. umbellata - p. pétalas da quilha com apêndice; q. cálice; r. ápice do estilete e estigma; s. estandarte (J. Rigon 90). t-w.V. unguiculata -t. estípula com a base triangular; u. cálice; v. ápice do estilete e estigma; w. estandarte (t C. Snak 306; u-w C. Snak 344).

Figure 3 - a-d. Vigna luteola - a. keel petals, flat-shaped; b. calyx; c. style apex and stigma; d. standard (C. Snak 268). e-i. V. peduncularis - e. stipule with truncate base; f. keel petals, laterally curved; g. calyx; h. style apex and stigma; i. standard (C. Snak 461). j-1. Vigna sp - j. calyx; k. style apex and stigma; 1 . standard (J. Cordeiro 1129). m-o. V. speciosa - m. calyx; n. style apex and stigma; o. standard (C. Snak 296). p-s. V. umbellata - p. keel petals with appendix; q. calyx; r. style apex and stigma; s. standard (J. Rigon 90). $\mathrm{t}$-w. V. unguiculata - t. stipules with triangular base; u. calyx; v. style apex and stigma; w. standard (t C. Snak 306; u-w C. Snak 344). 

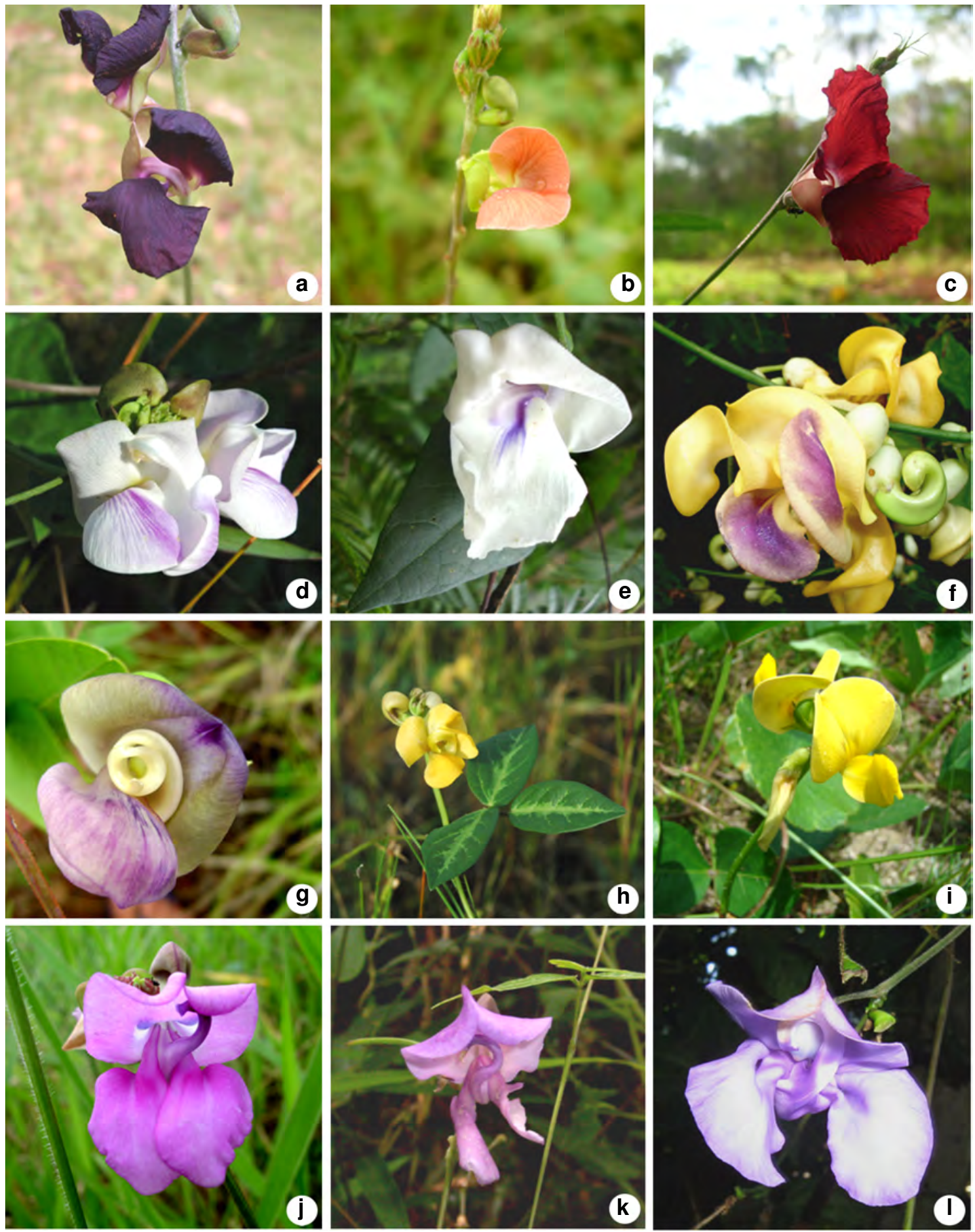

Figura 4 - Espécies de Phaseolinae no Paraná, Brasil - a. Macroptilium atropurpureum. b. M. erythroloma. c. M. lathyroides. d. Vigna adenantha. e. V. candida.f. V. caracalla. g. V. linearis. h. V. longifolia.i. V. luteola. j. V. peduncularis. k. Vigna sp. 1. V. speciosa. (Fotos: a, c \& 1 W. Mancinelli; g R. Queiroz; i: J. Rigon.).

Figure 4 - Species of Phaseolinae in the state of Paraná, Brazil - a. Macroptilium atropurpureum. b. M. erythroloma . c. M. lathyroides. d. Vigna adenantha. e. V. candida. f. V. caracalla. g. V. linearis. h. V. longifolia. i. V. luteola. j. V. peduncularis. k. Vigna sp. 1. V. speciosa. (Photos: a, c \& 1 W. Mancinelli; g R. Queiroz; i J. Rigon.). 
Ocorre nas Américas Central e do Sul (Maréchal et al. 1978). No Brasil, está presente nos estados do AM, BA, DF, GO, MG, MS, MT, PA, PR, RO, RS e SP(Moreira 1997; Perez 2010). No Paranáé encontrada em áreas com predomínio de estepe, cerrado, em borda de mata e beira de estrada.

Devido a espécie ser amplamente distribuída pelo estado, possuindo uma área de ocupação maior que $2.000 \mathrm{~km}^{2}$, considerada de preocupação menor (LC).

Vigna peduncularis geralmente apresenta folíolos heteromorfos no mesmo indivíduo, raque da inflorescência geralmente contraída, estandarte sem calosidades conspícuas como continuação dos apêndices basais e estilete prolongado além do ponto de inserção do estigma. Essas características a distinguem de Vigna sp., com a qual é muitas vezes confundida. Maréchal et al. (1978) admitiram três variedades para a espécie, reconhecidas pela forma e consistência dos folíolos. Para o Paraná não foram reconhecidas estas variedades, visto que alguns espécimes apresentam clara sobreposição de características. Floresce de dezembro a maio e frutifica de fevereiro a maio.

\subsection{Vigna sp. Figs. $3 \mathrm{j}-1,4 \mathrm{k}$}

Ervas volúveis. Estípulas 2-3,5 ×0,8-1,4 mm, lanceoladas a ovais, não expandidas abaixo do ponto de inserção, base truncada; pecíolo $1,2-12,5 \mathrm{~cm}$ compr.; folíolos basais $2-9 \times 1,3-5 \mathrm{~cm}$, lobados, assimétricos, triangulares, lanceolados a ovais, ápice agudo a acuminado, base truncada, obtusa a aguda, folíolo terminal 3-9 × 1-5,5 cm, inteiro ou lobado, simétrico, oval ou trulado, ápice agudo a acuminado, base obtusa, ambas as faces glabras a glabrescentes. Inflorescência 6-40 cm compr., glabrescente a pubérula. Cálice campanulado, 4denteado, tubo 3,5-4,6 mm compr., glabrescente a pubescente externamente; corola violácea; estandarte 16-22× 16-19 mm, assimétrico, ápice retuso, 1 par de apêndices basais e 1 par de calosidades como continuação dos apêndices basais; asas 19-26 × 5$12 \mathrm{~mm}$, alongadas a alargadas, esporão arredondado; pétalas da quilha 11-19 × 5,5-9 mm, lateralmente torcidas; estames 23,3-30,7 mm compr.; ovário 7-16 $\times 0,5-1 \mathrm{~mm}$ compr., pubescente; estilete $12-16,5 \mathrm{~mm}$ compr., prolongado além da região estigmática; estigma lateral externo. Legume 7-9 × 0,4-0,6 cm, pubérulo; 10-13 sementes, 4,3-5,2×2-2,5 mm, borda superior e inferior paralelas, castanhas.

Material selecionado: Arapoti, 10.IX.1960, fl., G. Hatschbach 7244 (MBM). Bocaiúva do Sul, 27.I.1970, fl., G. Hatschbach \& O. Guimarães 23415 (C,MBM).
Campo largo, 5.III.1983, fl., F. Chagas \& Silva 660 (FUEL). Campo Magro, 27.VIII.2005, fl., F.E.C. Marinero 18 (MBM). Jaguariaíva, 13.VII.2005, fl., E. Barbosa et al. 1081 (MBM). Ponta Grossa, 10.X.2003, fl.,R. Kaczmorch (HUPG 11446). Rio Branco do Sul, Itaperuçu, 8.VIII.1993, fl., J. Cordeiro 1129 (MBM). Sengés, 12.II.1997, fl., O.S. Ribas \& L.B.S. Pereira 1775 (MBM).

É encontrada nas Regiões Sudeste, CentroOeste e Sul do Brasil, no Sul estando restrita apenas ao Paraná, onde ocorre principalmente em cerrado e borda de mata.

Devido à espécie ter sido coletada em apenas 10 localidades no Paraná e possuir uma extensão de presença (EOO) pouco maior que $20.000 \mathrm{~km}^{2}$ pode ser considerada como quase ameaçada (NT).

Vigna sp. é uma espécie nova para a ciência e pode ser reconhecida pelo estandarte com um par de calosidades conspícuas como continuação dos apêndices basais, pétalas da quilha lateralmente torcidas e estilete prolongado além do ponto de inserção do estigma. Frequentemente confundida com $V$. peduncularis que, no entanto, não apresenta o par de calosidades no estandarte, e também com $V$. candida, a qual apresenta flores maiores e o estilete não é prolongado além da região estigmática. Coletada com flores de julho a janeiro e março e com frutos de novembro a janeiro.

4.10. Vigna speciosa (Kunth) Verdc., Kew Bull. 24: 552. 1970. Phaseolus speciosus Kunth, Nov. Gen. Sp.: 452.1823.

Figs. 3m-o, 41

Ervas volúveis. Estípulas 2,5-4,5 × 1-2 mm, lanceoladas a ovais, não expandidas abaixo do ponto de inserção, base truncada; pecíolo $1,3-6,5 \mathrm{~cm}$ compr.; folíolos basais 2,5-9,5 ×1-5 cm, inteiros, assimétricos, lanceolados a ovais, ápice agudo a acuminado, base obtusa, folíolo terminal 2,5-10 $\times$ 1,5-6 cm, inteiro, simétrico, oval ou trulado, ápice agudo a acuminado, base obtusa, face adaxial serícea, abaxial pubescente. Inflorescência 3-12 cm compr., pubescente. Cálice campanulado, 4-denteado, tubo 3-6,3 mm compr., glabro a esparso-piloso externamente; corola violácea; estandarte $22-30 \times$ 18-27 mm, assimétrico, ápice emarginado, 1 par de apêndices basais; asas $25-33 \times 10-18 \mathrm{~mm}$, alongadas, esporão obtuso; pétalas da quilha $26-32 \times 8-11 \mathrm{~mm}$, lateralmente torcidas; estames $39-43 \mathrm{~mm}$ compr.; ovário 14-17×1-1,2 mm, pubérulo; estilete 22-31 mm compr., não prolongado além da região estigmática; estigma terminal. Legume $8-10 \times 0,5-0,6 \mathrm{~cm}$, glabro; 7-13 sementes, $4 \times 2,5 \mathrm{~mm}$, borda superior reta e inferior convexa, castanhas. 
Material selecionado : Bocaiúva do Sul, 18.II.1960, fl., G. Hatschbach 6819 (C, HB, MBM). Cascavel, 16.I.2010, fl., C. Snak \& A. Snak 296(UPCB). Laranjeiras do Sul, fl. e fr., J.C. Lindeman \& H. Haas 4659 (MBM). Palmeira, 30.III.1983, fl., R. Kummrow \& Lynn Bohs 2252 (MBM). Ponta Grossa, 23.X.1914, fl., P. Dusén 1249 (GH). São Jerônimo da Serra, 25.II.1957, fl., G. Hatschbach 3608 (MBM). Teixeira Soares, 8.III.1990, fl., J.M. Silva 824 (MBM). Tibagí, 21.II.1953, fl., G. Hatschabach 3022 (MBM).

Segundo Piper (1926) e Maréchal et al. (1978), a espécie distribui-se na América Central até a Colômbia, Equador e Venezuela. No Brasil ocorre nos estados do DF, ES, GO, MG, MS, MT, PR, RJ e SP (Moreira 1997; Perez 2010). No Paraná ocorre em regiões com predomínio de estepe, cerrado e floresta estacional semidecidual, onde é encontrada em borda de matas e matas ciliares. O Paraná representa o limite austral de ocorrência da espécie no Brasil.

Pelo fato de ser encontrada em apenas oito localidades no Paraná é considerada como vulnerável(VU).

Vigna speciosa é caracterizada pelas pétalas da quilha lateralmente torcidas e estigma terminal com dois tufos de tricomas (fig. 3V). É confundida com $V$. candida, cujo estigma é oblíquo e o estandarte tem a margem da metade superior involuta. Floresce e frutifica de janeiro a março e em outubro.

4.11. Vigna umbellata (Thunb.) Ohwi \& H. Ohashi, J. Jap. Bot. 44: 31. 1964. Dolichos umbellatus Thunb., Trans. Linn. Soc. 2: 339. 1794.

Fig. 3p-s

Ervas eretas. Estípulas 6-7 × 1,8-2,1 mm, lanceoladas a ovais, expandidas abaixo do ponto de inserção, base triangular; pecíolo $2,5-10,5 \mathrm{~cm}$ compr.; folíolos basais 3,5-7 ×2-3,5 cm, inteiros, assimétricos, ovais, ápice acuminado, base obtusa, folíolo terminal 4-7,5 ×2,5-3,5 cm, inteiro, simétrico, oval ou trulado, ápice acuminado, base obtusa, ambas as faces glabrescentes. Inflorescência 2,5$13 \mathrm{~cm}$ compr., hirsuta. Cálice campanulado, 4denteado, tubo 2,2-2,5 $\mathrm{mm}$ compr., glabro a glabrescente externamente; corola amarela; estandarte 11,5-12×13,5-14 mm, assimétrico, ápice retuso, 1 par de apêndices basais e 1 calosidade mediana; asas 12-12,5×10-11 mm alargadas, esporão agudo; pétalas da quilha $12-12,5 \times 6,2-6,4 \mathrm{~mm}$, lateramente torcidas; estames 16,5-20 mm compr.; ovário 6-7,6 × 1-1,3 mm, pubérulo; estilete 9-15 mm compr., prolongado além da região estigmática; estigma lateral interno. Legume 7,5 ×0,5 cm, pubérulo; 8-11 sementes, 3-3,5×3-3,5 mm, borda superior reta e inferior convexa, de cor castanha.
Material selecionado:Cambé, 27.V.1985, fr., F. Almeida (FUEL 1255). Curitiba, 28.I.1975, fl., L.F. Ferreira 173 (MBM). Guarapuava, 4.II.2010, fl., J. Rigon 90 (UPCB). Londrina, 16.III.1979, fl., J. Marques 536 (FUEL).

Originária da Ásia (Maréchal et al. 1978).

No Paraná foi encontrada em cultivo nas regiões central e norte.

Devido à espécie ser cultivada no Paraná não é aplicável (NA) seu estado de conservação.

Vigna umbellata é caracterizada pelo prolongamento da estípula triangular, corola amarela e presença de um apêndice nas pétalas da quilha. Floresce de janeiro a março e frutifica em março.

4.12. Vigna unguiculata (L.) Walp., Repert. Bot. Syst. 1: 779. 1843. Dolichos unguiculatus L., Sp. Pl. 2: 725.1753.

Fig. 3t-w

Ervas volúveis. Estípulas 13,5-14×4-5,7 mm, lanceoladas a ovais, expandidas abaixo do ponto de inserção, base triangular; pecíolo $2-5 \mathrm{~cm}$ compr.; folíolos basais 6-15 ×4,5-9 cm, lobados, assimétricos, ovais ou trulados, ápice agudo a acuminado, base obtusa, folíolo terminal 6-13 $\times$ 5-8 cm, inteiro ou lobado, simétrico, oval ou trulado, ápice agudo a acuminado, base obtusa a aguda, ambas as faces glabras. Inflorescência 5$20 \mathrm{~cm}$ compr., glabra. Cálice tubuloso, 5-denteado, tubo 4,5-4,8 mm compr., glabro externamente; corola rosada; estandarte 23-25 × 23-28 mm, simétrico, ápice retuso, 1 par de apêndices basais e 1 par de calosidades medianas; asas 23-25 $\times$ 8,5-12 mm, alongadas a arredondadas, esporão obtuso; pétalas da quilha 23-24 × 9-10,5 mm, planas; estames 8-30 mm compr.; ovário 17-19× 1,4-1,5 mm, glabrescente; estilete 12-12,5 mm compr., prolongado além da região estigmática; estigma lateral interno. Legume $28-48 \times 0,7-1 \mathrm{~cm}$, glabro; 11-22 sementes, $11 \times 5,6 \mathrm{~mm}$, borda superior côncava e inferior convexa, de cor branca ou castanha.

Material selecionado: Cascavel, 17.I.2010, fl. e fr., $C$. Snak \& T. Snak 306 (UPCB).

Originária da África (Maréchal et al. 1978). Foi considerada como subespontânea por Perez (2010) nos estados de MG, MS, MT RJ e SP. No Paraná foi coletada em cultivo apenas no oeste do estado.

Devido à espécie ser cultivada no Paraná não é aplicável (NA) seu estado de conservação.

Vigna unguiculata é caracterizada pelo prolongamento da estípula triangular e pétalas da quilha planas. Floresce e frutifica em janeiro e fevereiro. 


\section{Agradecimentos}

Os autores agradecem aos curadores dos herbários, a permissão de consulta às coleções e empréstimo das exsicatas. Ao IAP e ICMBio, a concessão das licenças de coleta. A Rosane Quintella, as ilustrações. Ao CNPq, as bolsas de mestrado (C. Snak) e produtividade em pesquisa (R. Goldenberg e S.T.S. Miotto).

\section{Referências}

Barbosa-Fevereiro, V.P. 1987. Macroptilium (Bentham) Urban do. Brasil (Leguminosae - Faboideae Phaseoleae - Phaseolinae). Arquivos do Jardim Botânico do Rio de Janeiro. 28: 109-180.

Bentham, G. 1837. Commentationes de Leguminosarum Generibus. Typis J.B. Sollingeri, Vindobonae.

Bridson, D. \& Forman, L. 2004. The herbarium handbook. The Royal Botanic Garden, Kew. 346p.

Brummitt R.K \& Powell C.E. 1992. Authors of plants names. The Royal Botanic Garden, Kew. 732p.

Bruneau, A.; Doyle, J.J. \& Palmer, J.D. 1990. A chloroplast DNA inversion as a subtribal character in the Phaseoleae (Leguminosae). Systematic Botany. 15: 378-386.

Bruneau, A.; Doyle, J.L. \& Doyle, J.J. 1995. Phylogenetic evidence in Phaseoleae: evidence from chloroplast restriction site characters. In: Crisp, M.D. \& Doyle, J.J. Advances in legume systematics. Part 7: phylogeny. Royal Botanic Gardens, Kew. Pp. 309-330.

Burkart, A. 1943. Las leguminosas argentinas silvestres y cultivadas. Acme, Buenos Aires. 590p.

De Candolle, A.P. 1825. Leguminosae. In: De Candolle, A.P. Prodromus systematis naturalis regni vegetabillis. Vol. 2. Treuttel \& Whrtz, Paris. Pp. 93-424.

Delgado-Salinas, A.; Bruneau, A. \& Doyle, J.J. 1993. Chloroplast DNA phylogenetic studies in the new world Phaseolinae (Leguminosae: Papilionoideae: Phaseoleae). Systematic Botany 18:6-17.

Delgado-Salinas, A.; Turley, T.; Richman, A. \& Lavin, M. 1999. Phylogenetic analysis of the cultivated and wild species of Phaseolus (Fabaceae). Systematic Botany 24: 438-460.

Delgado-Salinas, A.; Bibler, R. \& Lavin, M. 2006. Phylogeny of the genus Phaseolus (Leguminosae): a recent diversification in an ancient landscape. Systematic Botany 31: 779-791.

Doyle, J.J. \& Doyle, J.L. 1993. Chloroplast DNA phylogeny of the papilionoid legume tribe Phaseoleae. Systematic Botany 18: 309-327.

Espert, S.M.; Drewes, S.I. \& Burghardt, A.D. 2007. Phylogeny of Macroptilium (Leguminosae): morphological, biochemical and molecular evidence. Cladistics 23: 119-129.

Fevereiro, P.C.A. \& Barbosa-Fevereiro, V.P. 1980. Nota prévia sobre as Leguminosae-Faboideae-Phaseoleae-
Phaseolinae do estado da Paraíba. Agropecuária Técnica 1: 197-202.

Fortunato, R.H.; Beyhaut, R.; Bortoluzzi, R.L.C.; Gómez-Sosa, E.V.; Izaguirre, P.; Lima, H.C.; Miotto, S.T.S.; Baptista, L.R.M. \& Ulibarri, E. 2008a. Fabaceae. In:Zuloaga, F.O.; Morrone, O. \& Belgrano, M.J. Catálogo de las plantas vasculares del Cono Sur. Vol. 2. Missouri Botanical Gardens Press, Saint Louis. Pp. 2287-2319.

Fortunato, R.H.; Beyhaut, R.; Bortoluzzi, R.L.C.; Gómez-Sosa, E.V.; Izaguirre, P.; Lima, H.C.; Miotto, S.T.S.; Baptista, L.R.M. \& Ulibarri, E. 2008b. Fabaceae. In: Zuloaga, F.O.; Morrone, O. \& Belgrano, M.J. Catálogo de las plantas vasculares del Cono Sur. Vol. 3. Missouri Botanical Gardens Press, Saint Louis. Pp. 2078-2286.

IAPAR. 2000. Cartas climáticas do Paraná. Disponível em: <http://200.201.27.14/Sma/Cartas_Climaticas/ Cartas_Climaticas.htm>. Acesso em 01 Mar 2010.

IUCN. 2001. International Union for Conservation of Nature and Natural Resources Red List Categories and Criteria: Version 3.1. IUCN Species Survival Commission. IUCN, Gland and Cambridge.

IUCN. 2003. Guidelines for application of IUCN Red List Criteria at regional levels: Version 3.0. IUCN Species Survival Commission. IUCN, Gland, Switzerland and Cambridge, UK.

Leitão-Filho, H.F. 1974. Contribuição ao estudo taxonômico do gênero Phaseolus L. no Brasil. Bragantia 33: 55-63.

Lewis, G.P.; Schrire, B.; Mackinder, B. \& Lock, M. 2005. Legumes of the world. The Royal Botanic Gardens, Kew. 577p.

Lima, H.C. 2010a. Lablab. In: Forzza, R.C. et al. 2010. Catálogo de plantas e fungos do Brasil. Vol 2. Jardim Botânico do Rio de Janeiro, Rio de Janeiro. Pp 1046.

Lima, H.C. 2010b. Phaseolus. In: Forzza, R.C. et al. 2010. Catálogo de plantas e fungos do Brasil. Vol 2. Jardim Botânico do Rio de Janeiro. Rio de Janeiro. 1077p.

Lima, H.C.; Queiroz, L.P.; Morim, M.P.; Souza, V.C.; Dutra, V.F.; Bortoluzzi, R.L.C.; Iganci, J.R.V.; Fortunato, R.H.; Vaz, A.M.S.F.; Souza, E.R.; Filardi, F.L.R.; Valls, J.F.M.; Garcia, F.C.P,; Fernandes, J.M.; Martins-da-Silva, R.C.V.; Perez, A.P.F.; Mansano, V.F.; Miotto, S.T.S.; Tozzi, A.M.G.A.; Meireles, J.E.; Lima, L.C.P.; Oliveira, M.L.A.A.; Flores, A.S.; Torke, B.M.; Pinto, R.B.; Lewis, G.P.; Barros, M.J.F.; Ribeiro, R.D.; Schütz, R.; Pennington, T.; Klitgaard, B.B.; Rando, J.G.; Scalon, V.R.; Cardoso, D.B.O.S.; Costa, L.C.; Silva, M.J.; Moura, T.M.; Barros, L.A.V.; Silva, M.C.R.; Queiroz, R.T.; Sartori, A.L.B. \& Camargo, R. 2010. Fabaceae. In: Forzza, R.C. et al. 2010. Catálogo de plantas e fungos do Brasil. Vol. 2. Jardim Botânico do Rio de Janeiro, Rio de Janeiro. Pp 989-1102.

Linnaeus, C. 1753. Species plantarum. Vol. 2. Laurentii Salvii, London. 1243p. 
Lollato, M.A.; Sepulcri, O. \& Demarchi, M. 2001. Cadeia produtiva do feijão: diagnóstico e demandas atuais. Vol 25. IAPAR-PR, Londrina. 48p.

Maack, R. 1981. Geografia física do estado do Paraná. BADEP/UFPR/IBTP, Curitiba. 350p.

Maréchal, R.; Mascherpa, J. \& Stainier, F. 1978. Etude taxonomique d'un groupe complexe d'espècies des genres Phaseolus et Vigna (Papilionaceae) sur la base de donées morphologiques et polliniques, traitées par l'analyse informatique. Boissiera 28:1-273.

Moreira, J.L.A. 1997. Estudo taxonômico da subtribo Phaseolinae Benth. (Leguminosae, Papilionoideae) no sudeste e centro-oeste do Brasil. Dissertação de Mestrado. Universidade Estadual de Campinas, Campinas. 292p.

Moura, T.M. 2010. Macroptilium. In: Forzza, R.C. et al. 2010. Catálogo de plantas e fungos do Brasil. Vol 2. Jardim Botânico do Rio de Janeiro, Rio de Janeiro. Pp 1054-1055.

NYBG. 2008. Index Herbariorum. Disponível em: <http:// sweetgum.nybg.org/ih/>. Acesso em 01 Nov 2010.

Perez, A.P.F. 2010. Vigna. In: Forzza, R.C. et al. 2010. Catálogo de plantas e fungos do Brasil. Vol 2. Jardim Botânico do Rio de Janeiro, Rio de Janeiro. Pp. 1099.

Piper, C.V. 1926. Studies in American Phaseolinae. Contributions of the U. S. National Herbarium 22: 663-701.

Polhill, R.M. \& Raven, P.H. 1981. Advances in legume systematics part I. Royal Botanic Gardens, Kew. 425p.
Radford, A.E.; Dickison, W.C.; Massey, J.R. \& Bell, C.R. 1974. Vascular plant systematics. Harper \& Row, New York. 891p.

Roderjan, C.V.; Galvão, F.; Kuniyoshi, Y.S. \& Hatschbach, G.G. 2002. As unidades fitogeográficas do estado do Paraná. Ciência \& Ambiente 24: 75-92.

Schrire, B.D. 2005. Tribe Phaseoleae. In: Lewis, G.P.; Schrire, B.; Mackinder, B. \& Lock, M. Legumes of the world. Royal Botanic Garden, Kew. Pp. 393-431.

Steele, W.M. \& Mehra, K.L. 1980. Structure, evolution and adaptation to farming system and environment in Vigna. In: Summerfield, D.R. \& Bunting, A.H. Advances in legume science. Royal Botanic Gardens, Kew. Pp 459-468.

Stefanovic, S; Pfeil, B.E; Palmer, J.D. \& Doyle, J.J. 2009. Relationships among phaseoloid legumes based on sequences from eight chloroplast regions. Systematic Botany 34: 115-128.

Wojciechowski, M.F. 2003. Reconstructing the phylogeny of legumes (Leguminosae): an early $21^{\text {st }}$ century perspective. In: Klitgaard, B.B. \& Bruneau, A. Advances in legume systematics 10: higher level systematics. Royal Botanic Gardens, Kew. Pp 5-35.

Wojciechowski, M.F.; Lavin, M. \& Sanderson, M.J. 2004. A phylogeny of legumes (Leguminosae) based on analysis of the plastid matK gene resolves many well-supported subclades within the family. American Journal of Botany 91: 1846-1862.

\section{Lista de exsicatas}

Abrão, H.R.S.: 197 (4.2); Acildo: 943 (2.3); Aguiar, N.H.: HUEM 662 (2.1); Almeida, F.: FUEL 1255 (4.11); Antunes, M.: FUEL 5422 (4.3); Athayde, S.F.: s.n. UPCB 24843 (4.1); Barbosa, E.: 1081 (4.9); Barros, C.: FUEL 25814 (4.6); Bianek, A.E.: 145 (2.4); Bidá, A.: 382 (2.3); Bortoluzzi, R.L.C.: 1253 (2.1); Braga, R.: 1610 (4.8); 1626 (4.7); Britez, R.M.: 103 (4.7); 1532 (4.6); MBM 111381 (4.6); MBM 125105 (4.1); MBM 219491 (4.1); MBM 219509 (4.6); UPCB 13907 (4.7); Buttura, E.: MBM 70135 (4.3); Carneiro, J.S.: 365 (2.1); Caxambú, M.G.: 215 (2.1); 420 (4.8); Cerrato, S.J.: HUPG 1691 (3.2); Cervi, A.C.: 6213 (2.5); 8566 (2.5); 9096 (2.3); 9244 (4.8); Chagas, F.: 557 (4.8); 660 (4.9); 1086 (4.3); 1521 (4.3); Corazzini, R.: FUEL 963 (4.3); Cordeiro, J.: 428 (4.5); 984 (2.2); 1129 (4.9); 1140 (4.9); 1916 (2.3); Corneli, V.M.: 19 (2.1); Costa, M.: FUEL 973 (4.3); Cruz, J.M.: 184 (2.1); 52 (2.3); Dalazoana, K.: HUPG 14704 (2.5); Dias, M.C.: 35 (2.1); FUEL 3644 (4.1); FUEL 3638 (4.7); FUEL 18198 (4.3); Diniz, J.M.: FUEL 1512 (3.2); Dombrowski, L.: 1493 (2.5); 6568 (2.5); 1601 (4.8); 1715 (4.8); 2214 (4.8); 2314 (4.8); 2472 (4.5); 2488 (4.8); 6505 (2.5); 689 (2.5); 690 (4.5); 9218 (2.5); 9571 (2.5); 10217 (2.5); 12340 (4.8); Dusén, P.: 1249 (4.10); 2684 (4.10); 2692 (2.3); 3147 (2.3); 3951 (4.10); 4118 (4.8); 4204 (4.10); 7340 (2.5); 8611 (2.5); 9550 (4.10); 11037 (2.3); 13527 (4.6); 13609 (4.7); 16254 (2.3); 16897 (4.8); 160306 (4.8); E 101/954 (4.8); R 66675 (4.5); R 66902 (4.8); Dutra, M.E.: HUEM 488 (2.1); Falcão, J.: 99 (4.3); Ferreira, C.R.: HCF 2359 (1.1); Ferreira, L.F.: 161 (3.2); 173 (4.11); 205 (4.2); Fontana, A.R.: FUEL 2823 (1.1); Freitas, O.T.: 168 (2.3); Garcia, R.S.: 23 (2.1); Gaudens, E.G.: UEC 37538 (2.2); Geraldino, H.L.C.: 288 (4.2); Gimenez, D.M.: FUEL 7891 (2.5); Ginsbarg, S.: 677 (4.5); Goetzke, S.: 44 (2.1); Goldenberg, R.: 599 (4.3); Gonzales, E.R.: FUEL 3031 (1.1); Gouvea, M.F.: FUEL 8374 (2.1); Gurgel: RB 59407 (2.5);Hahn, W.: 2341 (4.4); Hashimoto, E.M.: FUEL 1023 (1.1); Hassler, E.: 5535 (4.4); 6828 (4.4); Hatschbach, G.: 1688 (4.6); 1891 (4.2); 1893 (2.3); 1895 (4.5); 2569 (4.5); 3020 (4.8); 3022 (4.10); 3025 (2.3); 3120 (4.5); 3249 (4.3); 3494 (4.3); 3608 (4.10); 3609 (4.8); 4474 (4.1); 5895 (3.1); 6819 (4.10); 7244 (4.9); 7672 (4.2); 8071 (2.3); 8104 (3.1); 8869 (4.4); 8903 (4.5); 8937 (4.3); 11183 (4.2); 14153 (4.3); 14153 (4.3); 15966 (4.8); 16143 (4.9); 16154 (2.3); 16385 (4.7); 18454 (4.5); 18464 (2.3); 19027 (4.3); 19369 (4.3); 20731 (4.3); 21140 (4.8); 21152 (2.3); 21176 (4.5); 21391 (4.7); 22020 (2.2); 23415 (4.9); 23418 (2.3); 23462 (4.5); 26209 (4.2); 26295 (4.5); 26376 (4.3); 2766 (4.1); 28485 (2.3); 28555 (4.8); 33696 (4.7); 35524 (3.2); 35587 (3.2); 38358 (4.3); 39862 (4.3); 41077 (4.2); 41762 (4.9); 42783 (4.8); 44621 (4.2); 44811 (2.3); 46655 (2.3); MBM 8621 (4.4); Heringer, E.P.: 509 (4.12); 517 (4.12); 519 (4.12); Hertel, R.: 3 (2.5); Hirata, S.: HUEM 1273 (2.2); Hoehne, F.C.: UEC 69371 (4.7); UEC 69386 (2.5); Hoichi, F.: FUEL 4975 (1.1); Imaguire, N.: 213 (4.8); 2202 (2.3); 2273 (4.8); 3163 (4.5); Kaczmorch, R.: HUPG 11446 (4.9); Kawakita, K.: 1328 (2.1); Kita, K.K.: 155 (4.1); 751 (4.1); 799 (4.1); 875 (2.2); Kokubo, N.T.: HUEM 15091 (2.1); Kostin, A.J.: 93 (4.2); Kozera, C.: 19 (4.2); 3020 (4.5); Kranz, W.M.: 24 (4.2); 579 (4.8); 665 (4.3); Krapovickas, A.: 40777 (2.5); 40880 (4.8); 
Krieger, L.: 7299 (2.5); 7620 (2.5); 7635 (2.5); 19269 (3.2); UEC 69639 (2.3); UEC 70255 (2.5); Kummrow, R.: 257 (4.6); 476 (4.3); 892 (4.5); 1029 (4.3); 1205 (4.3); 1433 (4.2); 1790 (4.5); 1848 (4.5); 1864 (4.5); 2252 (4.10); 2266 (4.2); 2589 (2.3); 3029 (4.5); Kuniyoshi, Y.S.: 4635 (2.1); Laforga, A.L.: FUEL 6291 (2.1); Lewis, G.P.: 1388 (2.5); Lima, V.C.: UPCB 11352 (3.1); Lindeman, J.: 823 (4.3); 840 (4.2); 3634 (4.8); 4766 (4.8); 4659 (4.10); 4981 (4.8); 5324 (4.3); 5245 (4.7); Maistro, E.L.: 785 (1.1); Margarido, J.M.: HUEM 493 (4.3); Marinero, F.E.C.: 5 (4.9); 18 (4.9); Marques, J.: 536 (4.11); Mattos, H.B.: 373 (4.12); Medri, C.: 611 (4.3); Melo, E.: UPCB 24501 (4.1); Michelan, T.S.: 88 (2.2); Miotto, S.T.S.: 2361 (2.3); 2362 (2.3); 2368 (4.8); 2385 (2.3); 2387 (2.5); 2441 (2.1); Moreira, E.A.: MBM 213520 (4.8); Moura, C.: 96 (4.12); Moure, Pe. J.: 422 (4.6); Murakami, C.: FUEL 1514 (3.2); Occhioni: UPCB 5523 (2.5); Oliveira, P.I.: 698 (4.2); Pavão, O.C.: FUEL 24914 (4.3); Pereira, E.: 8326 (2.3); Pereira, L.F.: FUEL 1733 (2.5); Piatrowski, P.E.: HUPG 1089 (3.2); Pilati, R.: 04 (4.1); Policena, A.: 01 (4.3); Poliquesi, C.B.: 76 (2.5); 144 (4.9); Possette, R.: 177 (4.2); 179 (4.2); Pott, A.: 6204 (2.2); Prado, J.: 408 (4.6); Ramos, P.H.L.: HCF 7857 (2.1); Ribas, O.S.: 50 (4.6); 89 (4.7); 292 (2.1); 450 (2.3); 1036 (4.6); 1775 (4.8); 3179 (4.9); 5038 (4.8); Rigon, J.: 90 (4.11); Rosa, C.I.: 247 (4.1); Rufatto, W.B.: FUEL 11074 (1.1); Sampaio, A.: 3031 (4.12); Santos, E.: 2328 (4.5); Scudeler, A.: FUEL 4390 (1.1); Sekine, E.S.: 127 (4.2); Sem Coletor: HUPG 14366 (4.8); HUPG 14367 (2.5); MBM 219496 (1.1); Silva, E.M.: HCF 4076 (1.1); Silva, J.M.: J.M. 824 (4.10); 1078 (4.8); 3557 (4.9); 3695 (4.9); 4715 (4.3); Silva, M.N.: HCF 3768 (3.2); Silva, S.M.: 51 (4.1) (4.7); 238 (4.7); 283 (4.7); 1502 (4.7); 1905 (4.6); MBM 219508 (4.7); Silveira, M.: 102 (4.6); Slusarski, S.R.: FUEL 42032 (2.4); Smith, L.B.: 14916 (2.5); Snak, C.: 99 (4.10); 248 (2.1); 249 (2.1); 250 (2.4); 262 (3.2); 268 (4.7); 269 (4.6); 293 (4.6); 294 (4.6); 295 (4.7); 296 (4.10); 306 (4.12); 307 (3.2); 344 (4.12); 361 (4.7); 363 (4.7); 365 (4.1); 366 (4.7); 397 (4.6); 461 (4.8); 465 (2.3); 475 (4.2); 490 (4.3); 500 (4.1); 501 (4.6); 504 (4.7); 506 (4.1); 507 (4.6); 508 (4.7); Souza, J.M.T.: 01 (4.3); Souza, M.C.: 1344 (2.2); 1621 (2.2); 1781 (2.2); Spessoto, A.M.: 01 (2.1); Striquer, F.S.: FUEL 916 (4.7); Svolenski, A.C.: 292 (4.9); Takeda, I.: HUPG 9513 (2.5); HUPG 6643 (2.5); Tanak, T.M.W.: HCF 2579 (4.2); Tessmann, G.: 6132 (4.2): MBM 263814 (4.8); Tiepolo, G.: 268 (4.2); Torezan, J.M.: FUEL 11212 (4.7); Vedon, A.: HUPG 11354 (3.2); Vieira, A.O.S.: 664 (2.4); Yuzawa, S.K.: 965 (4.3). 